University of Nebraska - Lincoln

DigitalCommons@University of Nebraska - Lincoln

Zea E-Books Collection

Zea E-Books

$2-2-2022$

\title{
I Am a Cat, No. II
}

\author{
Natsume Sōseki \\ Kan-Ichi Ando
}

Follow this and additional works at: https://digitalcommons.unl.edu/zeabook

Part of the Comparative Literature Commons, Japanese Studies Commons, Language Interpretation and Translation Commons, and the Modern Literature Commons

\section{Recommended Citation}

Sōseki, Natsume and Ando, Kan-Ichi, "I Am a Cat, No. II" (2022). Zea E-Books Collection. 117. https://digitalcommons.unl.edu/zeabook/117

This Book is brought to you for free and open access by the Zea E-Books at DigitalCommons@University of Nebraska - Lincoln. It has been accepted for inclusion in Zea E-Books Collection by an authorized administrator of DigitalCommons@University of Nebraska - Lincoln. 

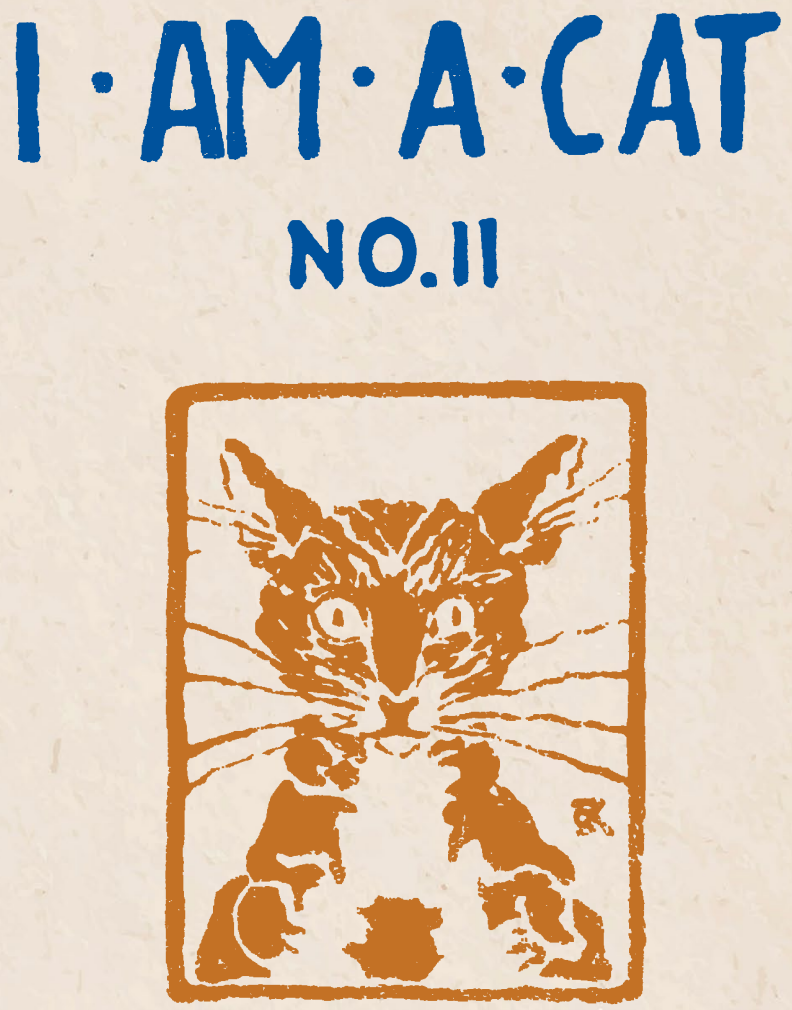

\section{TRANSLATED BY K ANDO REVISED BY K-NATSUME}


What would the neighbors say about you if they didn't know your cat was listening?

What if it was "The Cat With No Name"? The one who claims "I have, as a cat, attained the highest pitch of evolution imaginable. ... My tail is filled with all sorts of wisdom and, above all, a secret art handed down in the cat family, which teaches how to make fools of mankind. ... I am a cat, it is true, but remember I am one who keeps in the house of a scholar who reads the Moral Discourses of Epictetus and bangs the precious tome upon the table. And I claim to be distinguished from my heavy, doltish relations at large."

This volume is an English translation of Chapters III and IV of 吾輩は猫である Wagahai-wa neko de aru, which appeared in Japanese in 1902 and eventually ran to 10 installments. In these chapters we find the household of Professor Kushami entangled in the maneuvers of a possible engagement of Mr Kangetsu to Miss Kaneda and reacting with disdain toward businessmen and large noses and other unwelcome Western intrusions in Meiji Japan-all the while peppering their conversation with allusions to European science and literature.

ISBN 978-1-60962-234-3 ebook

doi: 10.32873/unl.dc.zea.1317

Zea Books,

Lincoln, Nebraska 


\title{
I AM A CAT. II
}

\author{
TRANSLATED \\ BY \\ KAN-ICHI ANDO. \\ REVISED \\ BY \\ KINNOSUKE NATSUME.
}

Zea Books

Lincoln, Nebraska

2022 
Published in Tokyo by Okura \& Co., 1909.

This volume includes English translation of Chapters III and IV of 吾輩は猫である Wagahai-wa neko de aru. The original of that work first appeared in 1902 and eventually ran to 10 installments or chapters. The author (and reviser) Kinnosuke Natsume is known under the pen name Natsume Sōseki.

ISBN 978-1-60962-233-6 paperback ISBN 978-1-60962-234-3 ebook doi: 10.32873/unl.dc.zea.1317

Zea Books are published by the University of Nebraska-Lincoln Libraries.

Electronic (pdf) edition available online at httos://digitalcommons.unledu/zeabook/

Print edition available from Lulu.com at htto://wwwsalulucom/snotlight/unllib

UNL does not discriminate based upon any protected status. Please go to htto://wwwwunledu/equity/ notice-nondiscrimination

\section{Nebraska \\ Lincoln}




\section{PREFACE}

$\longrightarrow \infty 0500$

A preface is a handy means of enabling an author to catch the "Gentle Reader" by the button (or by the ear, as the case may be!), and gently and calmly give him to know - various things! Now, sir, kindly lend me your ear! Thank you! I proceed then to inform you, good sir, of the raison d'être - there's scholarship in that phrase! — of this book. It was, certes, intended to follow hard upon the heels of my translation of the first part of this fascinating history of "Neko." This was published three years ago, and I set to work on the second part with such vim and velocity that in very short order, it was ready for the press. But here the wary or the wily publisher butted in, and for some reason best known to himself, - mayhap he thought my Englishing of the second part of Wagahai wa Neko de aru would, like good wine, improve with keeping - he laid by my MS. till just now.

As it was, I was led to conclude that the Cat made to appear in English dress by a bungling hand, would never be fit for the reading public; that he was destined to lie forever under heaps of literary matter in a neglected corner of some printing office. "Better late than never." As the popular adage has it, he has none the less reason to thank his stars now that he has been introduced to the world. 
The translation has been made with an eye to keeping as faithful as possible to the original text. I have used every endeavour to render a Japanese idiom by the corresponding English idiom as nearly as I could get; technical phraseology, provincialisms, dialect - every thing is turned into the nearest and most vivid equivalent I could discover.

At the same time the utmost care has been taken to retain the tone and savour of the pithy and suggestive language for which the original work is noted. I am inclined to think that a longer acquaintance, a closer intimacy, with the astute, knowing Cat and his two-legged associates has enabled me to undertake the present section of the story with clearer fidelity, a surer touch; but this, my dear Gentle Reader, I leave to you to judge.

In conclusion, I wish to express my acknowledgments to Mr. Natsume, the original author, for his revision, and Prof. E. B. Clarke of the First High School, for his invaluable suggestions which have gone a long way toward setting this translation in trim.

\section{KAN-ICHI ANDO.}

KAGOSHIMA, APRIL, 1909. 


\section{AMACAT \\ -}

\section{CHAPTER III.}

Dear Mikè is no more, and as Black is not an agreeable companion I feel a bit lonesome. To make up for this, however, I have made new acquaintances among human creatures. So you see, time does not hang so heavily on my hands.

The other day, a gentleman wrote to my master, requesting him to send my picture. A day or two later, I had a favor shown me by another gentleman who went to the trouble of sending me a gift of the famous Okayama Kibi-dango (millet dumplings). What pleased me most was that it came to my own address. With the increasing sympathy shown me by human beings, I am often led to forget that I am a cat, feeling myself drawn to them rather than to my own kith and kin.

As things stand, such an idea as gathering our race to rise against the two-legged creatures never crosses my mind. What is more, I sometimes wonder if I am not an actual member of their society, and then I hug myself upon the wonderful development I have made. You must not think by this that I am 
making light of my own family. I only mean to say that it is to a kindred disposition that we are naturally attracted and look to it for our well-being. One does me a wrong to explain away this natural inclination by the mean quality of a turn-coat; weather-cock or traitor. In fact, those who attack others with such language are, most of them, tactless fellows destined to eternal poverty.

Having thus divested myself of my old ways, I cannot always be brooding over the dead Mikè and the unruly Black. I am disposed to hold my head as high as man, and to criticize his actions. This, too, may be deemed a natural turn of mind. Only what is hard to bear is that my master thinks me little better than an ordinary cat, - me who am of so exalted a mind. He has eaten up all the Kibidango without so much as asking my consent, as if the present had been made to him. Nor does it seem that he has had my picture taken and sent. I cannot of course overlook this state of affairs. But it is only natural that two men should be of two minds. I have then only to act the part of man ad unguem. As a matter of course, my pen is idle regarding cats with whom I have nothing in common. So you will excuse me if I give an account only of my old friends, Messrs. Meitei, Kangetsu, and the rest. 
One fine Sunday, my master crawled out of his den and lay down beside me with pen and ink and some sheets of paper, muttering something under his breath. I watched him, thinking this murmur a prelude to his usual performance of ink-daubing. After a while, he dashed off in a bold hand "A stick of incense." This was too neatly put for my master, and I was curious to see what it would make, a Chinese poem or a Haiku. It was not long, however, before I saw him stop short, his pen skipping over to the next line and running: "I have been thinking all the while to write of Tennen-koji." Here the pen came to a stand-still.

The writer twisted his head with the idle pen still in hand. But nothing bright apparently came into his mind; for he soon began nibbling the tip of his pen, which dyed his lips black. He then drew a circle, marked the eyes in it with two dots, scratched an ugly upturned nose in the centre, and added a mouth by drawing a line with one bold stroke. Such was the result of my anticipation! Nor had my master a word to say for himself before this daub; he proceeded at once to blot it out. He then changed a line, and ransacked his brains at random. It seemed, in his opinion, that by merely renewing a line something or other would eventually be produced. 
After a while, he jotted down at a stroke in the Gembun-itchi Style $\$$ - “Tennen-koji was an individual who studied space, read Rongo, ${ }^{*}$ ate baked potatoes, and let his nose run." I thought there was something loose and confused in this wording. But my master without hesitation read it aloud and gave vent to an unwonted laugh.

"Good! Ha! ha! ha! But 'let his nose run," he chuckled, "is too coarse a remark. Better strike it out." He drew a line through the phrase. Then he added another as if one line were not enough, and still another, all in nice parallels, until they stole a march upon the next line. Although they thus finally numbered eight, no happy thought came to continue the sentence.

$\ddagger$ A style of writing in which the spoken and the written language are unified. It was introduced by Yamada Bimyosai and other literati; and now popularly adopted.

* A book of moral teachings by Confucius. It makes one of the so-called Shisho Gokyô (the Four Books and the Five Canons) which comprises the best of the Chinese Classics. The doctrines of this sage have for ages exercised great influence over the moral character of the Japanese, not to say anything of her neighbors, the Chinese and the Koreans, who still make them their sole code of ethics. 
Hereupon he laid down his pen, and began to twirl his moustache up and down, and that in such a manner as though he expected to twirl out an excellent piece of literary work.

Just then his wife came out of the sittingroom and sat down right in front of him.

"Just a word, my dear!" she said.

"What do you want?" retorted her husband, in a tone of a gong struck under the water.

"Just a word, I say!" repeated the other, apparently dissatisfied with this tart reply.

"What's that?" demanded my master, jerking out one or two spears of his sparse beard.

"We are a little pinched this month."

"No such thing, I believe. We've already paid the doctor's bill, and last month my book bill. We ought to have some money left over," said he coolly, gazing at the hairs he had pulled out, as if they were one of the Seven Wonders of the World.

"But then, you see, instead of the ordinary food, you've eaten bread and jam."

"Say how much jam has been consumed?"

"Eight tins this month."

"Eight? Upon my word, I've not taken that much."

"But our little ones also had their share."

"It's not a heavy pull upon the purse after all. Five or six yen at most, I am sure." 
He said this carelessly, planting, one by one, the wires he had plucked out, on the paper. The hairs with their sticky roots stuck fast, straight up like so many needles. With a sort of wonder at this chance discovery, my master tried to blow them off, but failed in the attempt on account of their strong adhesive power. "How tenacious!" cried the great discoverer, making another trial with violent efforts.

"It's not only jam;" resumed my mistress. "There are many other things to be purchased."

"Yes, may be," answered the other, in an indifferent tone, and pulled out a few more hairs, which were of all manner of colors, red, black, brown; and there was, among the rest, a white one. He studied it closely for a time, with a look of amazement, and then holding it between his thumb and finger he fairly thrust it into his wife's face.

"No joke, sir!" She knitted her brow and repulsed his hand.

"See that. So early turned as white as snow!" He appeared much impressed with what he had found, while his wife, no longer able to keep her countenance, retired to the sitting-room, laughing. She appeared to have given up the intended discussion on the 
economic question as it touches the home. My master again attacked his Tennen-koji.

Now that he had sent his wife away by means of a droll trick, he resumed his work with a look of relief. With his fingers still plucking at his beard, he strove impetuously to find words to express himself, but in vain.

“'Ate baked potatoes' is rather out of place; it can be dispensed with," he said, and blotted it out. "'A stick of incense,' is too abrupt a beginning. Better omitted." Nothing loth, he erased it likewise. So that the recast sentence ran thus: "Tennen-koji was an individual who studied space and read Rongo." He mused a while, obviously thinking it too short as it was.

"Out with this troublesome writing!" he exclaimed at last; "let me be content with dedicating a few lines to his memory." With a lively flourish of his pen, he began to daub an orchid after the fashion of Bunjin-ga*, thus destroying his elaborate literae scriptae to a letter. He then turned the other side of the paper, and indited ambiguously as follows: -

* Also called Nan-ga, a Chinese style of drawing first originated in the Sô Dynasty and most prevailed in the Min and the Shin Dynasties. First introduced into this country at an early period of the Tokugawa Shogunate. 
Born in space,

Thou studiedst space,

And diedst in space, -

All as void as space.

Alas! Poor Tennen-koji.

Just at that moment, in came Mr. Meitei, who, to all appearances, made no distinction between other men's houses and his own. He stepped in freely without giving them the trouble even of asking him in. More than that, he sometimes even came in unexpectedly by the kitchen door. He is a man who shook off in his cradle all such sentiments as care, modesty, diffidence, and so on.

"Writing of 'Giant Gravitation,' eh?" asked the intruder, while still standing.

"No, I am not always at that, but am composing an inscription on Tennen-koji," returned my master, in a pompous way.

"Is that similar to a posthumous name, such as Guzen-dôshi?" Meitei usually fired a random shot.

"Is there such a name?"

"No, there isn't. But I say the one savors much of the other."

"I do not remember anyone of the name of Guzen-doshi, but Tennen-koji was a man you know." 
"And who was it that contented himself with such a name, I pray?"

"No other than Sorosaki. After graduation, he entered the Post-Graduate Department and was preparing a thesis upon the subject of space. But as a result of overstudy, he got inflammation of the peritoneum, which put an untimely end to his career. You know, he was a crony of mine, this Sorosaki."

"Well, I've never said he wasn't. But who on earth has changed his name to Tennen-koji?"

"I have. I gave him that name, for, as you see, nothing is so commonplace as the posthumous names* given by priests," bragged my master, as if "Tennen-koji" were a most elegant kaimyô.

"Well, let me see what you call his inscription," said Meitei, laughing, while he took up the paper. "Let's see, - 'Born in space, thou studiedst space, and diedst in space, - all as void as space. Alas! Poor Tennen-koji," he read in a loud voice. "It's fine," he said, "and a most becoming inscription for "Tennen-koji”"

* Each Buddhist has a hômyô or kaimyô chosen for him, immediately after death, by the priest, and inscribed on the funeral tablet. Such names generally end in koji, in, shinji, doji, \&c., according to the age, sex, rank and sect of the deceased. 
"You think it fine, too?" observed my master, highly delighted.

"Engrave it on a takuan-ishi, $\$$ and leave it behind the Buddhist temple - in the grave yard of which the dead man lies - in the same manner as that in which the chikara$i s h i^{*}$ is placed. It would then look tasteful, and besides, Tennen-koji could enter Nirvana."

"I am thinking of doing that," replied my master, with great solemnity. "Excuse my going out for a while," added he abruptly; "I shall soon be back. In the meanwhile, amuse yourself by toying with the cat." Before the other could say "Yatoton Torusuke," my master made his exit.

Now that I was incidentally left to entertain the company, I could not very well remain indifferent. Thereupon I went and got upon Meitei's lap, complimenting him with my sweet mewing and purring. "Hullo! You've grown very fat. Let's see how much you weigh," said he, and snatched me up by the scruff of the neck without ceremony. "Ah, you are not well up in catching rats; I can see

$\ddagger$ A stone used as a weight to press dried radish pickled in a mixture of rice bran and salt (takuan).

* A big stone, usually of an oblong shape, which is lifted by an athlete called chikara-mochi. 
it by the way you dangle your hind legs Say, madam; is this cat a good ratter?" he addressed my mistress in the next room, as if not quite content with my company only.

"That he is; and not only a ratter, but a dancer, even with a piece of mochi in his mouth." Little I thought my past misdemeanor would be blurted out in such a manner. Swinging like a pendulum as I was, I could not but feel a little abashed. Nor would Meitei let go his hold.

"Indeed, his features betray it, madam. His physiognomy is anything but prepossessing. It represents the nekomata $\$$ of old story books." He carried on his idle talk to engage the attention of my mistress, who reluctantly stopped her sewing, and came to the drawing room.

"I've no doubt you're tired. But my husband will be back in a few moments, I am sure," said my mistress, giving a fresh cup of tea to the guest.

"Where has he gone?"

"I can't tell. He never gives me a hint as to where he is going. Ten to one, he has gone to the doctor's.

$\$$ A wild cat said to have a forked tail and a bewitching power, supposed to have been transformed from an old domestic cat. 
"Do you mean Dr. Amaki? I think he must find it difficult to deal with such a patient, don't you?"

"Yes I suppose so --" was the only answer from my mistress, who was evidently at a loss for a reply.

"How is Kushami-kun's indigestion of late? A little better?" he continued aimlessly.

"I am sure I don't know. Notwithstanding all Dr. Amaki's attention, there is no chance of his getting well so long as he continues to tickle his palate with so much jam." She thus indirectly gave vent to her feelings of dissatisfaction caused by that grave financial dispute mentioned before.

"Is he such a jam eater? Why, how childish!"

"Nor does he stop at jam. Grated radish is his latest fad; he declares it a sure cure for indigestion -"

"Dear me!" exclaimed Meitei.

"It is since he read in a paper that grated radish has a great deal of diastase in it, or some such thing."

"He means to repair the damage caused by jam. He is indeed a most learned hygienist. Ha! ha! ha!" laughed the guest, much delighted with the fault-finding of my mistress.

"The other day, he even made our baby taste - " 
"Jam?"

"No, grated radish - saying 'Come here, darling, pa will give you something nice.' It's very seldom that he caresses the children; and even then only to play a trick on them. Two or three days ago, he took our second girl in his arms, and put her upon a chest of drawers, and -"

"What was his plan?" interrupted Meitei who expects everything he hears to have some plan in it.

"No plan at all! He simply told her to jump down. But how could a little girl of three or four act the part of a tomboy?"

"Really! That was nonsensical. But he is a good man after all, having not a drop of bad blood in him."

"If he had, there would be no living with him." Carpingly continued my mistress.

"Come, come, don't be so discontented. You have compensations, you know. It's a blessing that you can enjoy life each day without want. It's a blessing also to have such a husband as Mr. Kushami who, never going astray nor being particular about his appearance, has been created on a simple and economical plan." Meitei was delivering an unbecoming sermonette in a loud lively tone.

"But the fact is very different - " 
"Any latent plot at times? That's the worst of the world." Meitei threw in this jaunty remark.

"He has no bad habits, except that he invests too freely in books that he seldom, if ever, reads. I don't say this is bad, but I mean he should act with more discretion. He goes to Maruzen whenever he feels so disposed and buys on credit as many books as he wants. And he leaves me quite in ignorance of it, even when pay-day comes. In fact, I had a most difficult task at the end of last year to clear off all arrears."

"But, madam, it does no harm to get any number of things such as books. If a collector comes to dun, keep telling him you will pay soon, and then he will be off."

"But, you know, payment cannot be put off forever," said my mistress glumly.

"Then you had best tell your husband how affairs go and have those particular expenses curtailed."

"Why, that is next to an impossibility. The other day, he complained: 'You don't know the value of books at all, in spite of your being a scholar's wife. Listen! I will tell you an old Roman story for your future benefit."'

"That's amusing! What story was it?" This question was prompted by his curi- 
osity rather than by his sympathy for my mistress.

"To the best of my recollection, his story was to this effect: - There was once in Rome a King called Tarukin or some such name"-

"Tarukin? That sounds a bit strange."

"My memory can hardly retain the awkward names of foreigners. He was of the seventh generation, if I remember rightly."

"Tarukin VII! That's very suggestive. I declare! And what happened to that Tarukin VII?"

"Poor me! Even you poke fun at me. If you know it, why don't you tell me? You are trying to take a rise out of me, sir," said my mistress accusingly.

"Poke fun at you, do you say? Not in the least, madam! I am not such an inveterate wag. Only the name has for me a funny association - Wait a bit; you said the Seventh King of Rome? Let's see. I am not quite certain, but wasn't he Tarquin the Proud? However any king will do. Go on with your talking - I mean story."

"A woman came one day to that monarch with nine volumes of books, and asked him to buy them."

"I see!"

"When asked the price, she named an 
extravagant figure, so extravagant that the King bade her make some reduction. No sooner had he said that, than the woman seized three volumes out of the set, threw them into a fire and burned them."

"What a pity!"

"They contained some valuable prophecies impossible to obtain elsewhere."

"Oh, indeed!"

"The King now demanded the price of the remaining books, believing that the loss of the three copies would moderate her charge. Still she would not deduct even a farthing from the original price. The King protested that she was unreasonable. Thereupon, she reduced another three volumes to ashes. 'Now, woman, what is your charge for the three that are left? ' asked the sovereign who still hankered after them. 'The same price, Your Majesty,' insisted the woman. The nine volumes were reduced to six, and the six to three, and those three would ultimately have become none, had any discount been asked. In the circumstances, the King had to pay the original high price to save them from destruction - . 'Now,' continued my lord and master triumphantly, 'you can no doubt recognise somehow the virtue of books by this story?' To speak the truth, however, I failed 
to see where this so-called virtue of books lay." Having thus formulated her own opinion, my mistress urged Meitei to say what he thought about it. Resourceful as he is, he was obviously in a fix at having to make a witty and sufficient reply on the spur of the moment. He pulled out a handkerchief from his pocket, and was trying to make me gambol with it.

"But, madam," and he broke the silence with a loud voice, as if something had suddenly flitted across his mind. "It's because he dips into a multitude of books that they regard him as a sort of learned man. The other day, while reading a literary magazine, I came across a reference to $\mathrm{Mr}$. Kushami."

"Oh, did you really?" She altered her attitude, anxious to hear of the fame of her husband, - sparks of connubial affection. "What did it say?"

"It was only a few lines, saying that the compositions of Mr. Kushami were like swiftly passing clouds or flowing water."

"Was that all?" questioned my mistress smartly.

"No, it was followed by the phrase: 'Now in sight, and now gone; once gone, gone forever."” 
Here she looked put out. "Was that intended for commendation?" she inquired apprehensively.

"Well, yes; I should say so," replied Meitei coolly, dangling his handkerchief before my eyes.

"Admitting books are an absolute necessity to one of his profession, he is too whimsical in his ways."

"Ah, she has another bone to pick," thought Meitei, and said: "Yes, he is eccentric to a certain extent. But that's the case with most of those who make learning their trade." This expedient reply had the double effect of pleasing the wife and pleading for the man.

"To give an example, a few days ago, he got back from school, and was to go out again somewhere immediately. He was loath to give himself the trouble of changing his dress. So he sat down upon the tsukue, with his overcoat on. Then he put his plate upon the kotatsu-yagura, $\neq$ and began to eat. I looked on with the ohachi (rice-tub) beside me; the sight was so laughter-provoking."

"That suggests a scene of inspecting the

$\$$ A wooden frame over a kind of hearth (kotatsu) for supporting the quilt, under which people warm themselves. The Japanese equivalent for the Western warming-pan or hot water bottle. 
head of an enemy in quite an up-to-date fashion. But that is just what Mr. Kushami would do. At any rate, it's not tsukinami," * was Meitei's awkward praise.

"Tsukinami or no tsukinami," it is more than I know. I simply state that he indulged his whim to an inexcusable degree."

"But it is preferable to tsukinami." Meitei persistently stood by her husband to the apparent mortification of the other.

"I hear them use 'tsukinami' time and again. What on earth does it signify, sir?" my mistress asked for the definition of tsukinami looking as grave as a judge.

"Tsukinami? Well - er - that is, you know - . It's a bit hard to explain."

"If it is of such a doubtful nature, am I not correct in looking at his action in the light of the so-called tsukinami?" she persisted by means of subtle reasoning peculiar to the opposite sex.

"It's neither doubtful nor ambiguous. On the contrary, it's very plain to me. The only point is how to put it into words."

"It means what one dislikes, doesn't it?" she unwittingly gave a practical definition.

* For the explanation see Vol. I. page 73. [Commonplace verse] 
As the matter stood, Meitei could not but try to despatch the case somehow or other. "Madam, what they call tsukinami," he began, "originally means a class of great writers who always dawdle betwixt 'Toshi wa nihachi ka nikukaranu' ' and 'Iwazu katarazu mono omoi,"* and who invariably accompany 'the day was fine,' with 'So I took a stroll toward Mukôjima, carrying a hyô ${ }^{\dagger}$ with me."”

"I wonder if there is such a class of men," said my mistress, in a perplexed manner, for she was quite at sea. The next moment, however, she hauled down her colors, confessing: "I cannot understand you. What you say is a regular riddle."

"Then, set the head of Major Pendennis on the body of Bakin, and have it enveloped in Occidental atmosphere, say, for a couple of years."

"Is tsukinami produced then?"

But Meitei responded with a cynical smile. "Yes, that's one way," he said after a time, "but we, are not necessarily required to resort

¥ A stale figure used for describing a lovely girl on this side of twenty. The three following dictions are equally dull and commonplace.

* To be moody, not giving utterance to what one has in his or her mind.

† A gourd dried and hollowed to contain sakè. 
to such troublesome means, for there is an easier way to make it. Take a graduate of a middle school, add a clerk of a dry-goods store, and divide by two; then you will get a typical tsukinami."

"You don't say so!" said my mistress, shaking her head, not knowing which way to turn.

"Ah, are you still here?" said my master, who coming back without warning, took a seat by the side of Meitei

“'Still here?' That's too pointed a remark, man. You told me to stay as you would soon return."

"That's the way with him!" put in my mistress, turning to Meitei.

"During your absence, I had the pleasure of hearing all sorts of anecdotes about you," said Meitei.

"That's the worst of women. Their tongues are always busy. I wish mankind could keep as silent as this cat does," observed my master, stroking my head.

"You made your child taste grated radish?"

"Yes," returned he, with a laugh, and continued: "The little ones of the Twentieth Century are up to snuff. Since that experience, our little one is sure to stick out its tongue, whenever I ask where it felt hot."

"Dear me! That's just like training a dog! By 
the bye, it's time Kangetsu put in his appearance."

"Is he to come here?" questioned my master wonderingly.

"Yes, he is. I dropped him a line asking him to call in here by one this afternoon."

"Not even consulting my convenience? Sheer presumption! And what is up?"

"Why, the affair of to-day has nothing to do with my plan; it's according to Kangetsu's request. He says he is going to deliver a speech at a meeting of a Scientific Society. Consequently, he has asked me to hear him rehearse. 'All right,' I assented, 'Kushami shall share the treat,' - hence this arrangement. Faith, you can well afford to please him, as you are always at leisure, - the last man to have an engagement. Yes, you shall give him a hearing," prattled the self-complaisant guest.

"I have no ear for a speech on physics," cried my master, as if a little indignant at Meitei's forced arrangement.

"But on what do you think he will speak? - Not on such stale topics as 'magnetized nozzle,' etc., but on quite a new-fangled one called 'A Dynamical Study of Hanging,' - a speech certainly worth hearing."

"You would do well to hear it, - who once 
attempted hanging yourself. But I - "

"'But I who shuddered at the Kabukiza affair can ill afford to hear,' eh? No such conclusion, if you please," Meitei rattled on with a flippancy all his own. My mistress laughed, and glancing at her husband retired into the next room, while he stroked my head in silence; he had never stroked me so tenderly.

Some seven minutes had passed, when Mr. Kangetsu appeared according to arrangement. He was unusually dressed up in a fine frockcoat and a high starched collar, in which he looked twenty per cent. handsomer than usual. In fine, his air was in keeping with the great speech he was to deliver that evening.

"Good afternoon, I am sorry I have been delayed," was his salute, in a quiet, formal tone.

"We have been waiting and waiting for you. I hope you will begin at once, don't you?" said Meitei, turning to my master, who, as the occasion required, assented, but in a halfhearted way.

"Give me a glass of water, please," asked Mr. Kangetsu, in an important tone.

"Ah, you are going to speak in a regular formal style. Very likely you'll call next for our cheers," twaddled Meitei noisily, well pleased with himself.

Mr. Kangetsu pulled out papers from his 
inner pocket, and said slowly: "This is a rehearsal, you know. Therefore, your candid criticism will be welcome." With this preparatory remark, he began: -

"Gentlemen: - The execution of criminals by means of hanging was a punishment chiefly practised among the Anglo-Saxon race. If we trace it back to more ancient times, we find that hanging was commonly resorted to as a means of self-destruction. The punishment of death by stoning seems to have prevailed among the Jews. A perusal of the Old Testament shows that by the word 'hanging' was meant hanging of the corpses of prisoners to feed wild beasts and birds of prey. According to Herodotus, the Jews, even before they escaped from Egypt, held in abomination the idea of their bodies being exposed at night. The Egyptians are said to have beheaded their criminals, nailed their trunks to crosses, and left them out over night. The Persians - "

"Beware, Mr. Kangetsu! It seems to me that you are step by step going out of your way," Meitei put in a warning note.

"A little patience, please. I shall be back to my original topic soon. - Well, coming to the Persians, it appears they also used crucifixion as their mode of execution. But whether 
they did it while the victim was alive or after death, is more than I can discover."

"It's not worth while searching out such matters," yawned my master wearily.

"I could give you many other examples; but as I fear they might prove a wet blanket - "

"The simple word 'boring' is more to the point than a wet blanket, besides sounding smoother. Isn't that so, Mr. Kushami?" was Meitei's snub.

"They are all pretty much of a muchness, anyway!" replied my master drily.

"Now, I shall enter upon my original discourse and talk - "

"Talk?" twitted the word-catcher again; "Why, that's a word becoming a low storyteller. A public lecturer should choose more refined language."

"If 'talk' is so homely a word, how shall I express myself?" demanded the speaker, in an excited tone.

"It's hard to tell which Meitei is doing, listening or disturbing. Turn a deaf ear to the noisy meddler, Mr. Kangetsu, and push on!" suggested my master, who sought to keep out of trouble.

"How now," said the wit-worm, in his usual mocking manner, "I have a haiku: 'Behold how the angry talker talks, a weeping 
willow toss'd in a gale."' Mr. Kangetsu burst out laughing in spite of himself.

"According to my investigation," resumed the speaker, "hanging, in the strict sense of the word, was first made use of in the case of the execution of Penelope's twelve female attendants by Telemachus, as the twentysecond volume of the Odyssey has it. I might recite the passage in Greek. But this I forbear lest I should appear pedantic. You will get the text between lines 564 and 473 -."

"You had better avoid your reference to Greek this evening. It sounds too much as though you were quite at home in that classical language. Don't you think so, Mr. Kushami?"

"Yes, I indorse Meitei's opinion. Such airs fit a prig rather than a respectable speaker." On this particular occasion, my master was not slow to take the side of Meitei. As a matter of fact, neither of the scholars had even a smattering of Greek.

"Then I shall leave out the text this evening, and talk — speak on. There were, as my imagination pictures, two methods of carrying out the hanging in question. The one was evidently done in this way: Telemachus, assisted by Umius and Philisius, tied one end of a rope to a pillar. The rope was prepared 
with a number of loops, into which the women's heads were thrust. Then the other end was pulled with a mighty strength."

"The victims swung like so many shirts hanging on a clothes line. Am I right in my fancy?" interposed Meitei.

"Yes, exactly. The other process was that one end of a rope was likewise fastened to a pillar, but in this case the other end was at the same time hooked up to the ceiling. Then several pieces of looped cords were attached to the suspended rope. Next the women's heads were inserted into the loops, and the displacement of the footstools on which they stood, completed the fatal process."

"We might call up a picture of many chochindama $a^{\ddagger}$ dangling at the ends of nawa-noren*?" put in Meitei again.

$\ddagger$ The translator himself does not know what this is like. Imagine some fantastic ball resembling a round lantern, and the reader may not be far from the mark. It may be added that this curious ball is included in the humorous expression often used by Tokyo people, "me-dama hyokkuridama chochin-dama ke-dama."

* A kind of curtain which is made of long strips of twisted straw fastened to a piece of bamboo, and is hung mostly before the lowest class eating-houses. The word often signifies such public-houses themselves. 
'I can't say 'yes' or 'no,' since I have never seen a chôchin-dama in my life. But if such balls exist, I think you are about right. Now, I am going to prove from a dynamical point of view, that the first case of hanging is quite impossible."

"That's amusing," interjected Meitei.

"Yes, quite amusing," echoed my master.

"Suppose the relative distance the women were hanged, was the same; and suppose the rope holding the two women nearest the ground, was horizontal. And $\mathrm{a}^{1} \mathrm{a}^{2} \ldots \ldots \mathrm{a}^{6}$ were angles the rope made at the horizontal line, and $t^{1} t^{2} \ldots \ldots t^{6}$ the tension exerted at every part of the rope. $T^{7}=\mathrm{x}$ was the force or tension at the lowest part of the rope. Take $\mathrm{W}$ as the weight of the women. Now, do you understand me?"

"Yes, nearly," said both the listeners, looking at each other. But this "nearly" vaguely expressed the extent of their own want of comprehension, and therefore it was a question how far it was applicable to others.

"Now, according to the theory of equilibrium relative to polygons, the following twelve equations are produced: $-\mathrm{T} \cos \mathrm{a}_{1}=$ $\mathrm{T}_{2} \cos _{2} \ldots \ldots$ (1) $\mathrm{T}_{2} \cos \mathrm{a}_{2}=\mathrm{T}_{3} \cos \mathrm{a}_{3} \ldots \ldots$ (2) -

"Haven't we had enough of equations already?" rudely interrupted my master. 
"To tell the truth, these very equations form a fundamental part of my lecture," responded the speaker, loath to give them up.

"Then let us hear of that fundamental part some other day," proposed Meitei, apparently as deep in the mud as was my master.

"If I were to set this formula aside, my elaborate investigation in dynamics could entirely lose its lustre, and -"

"Have no such anxiety, sir. Throw them clean overboard," suggested my master indifferently.

"Then following your advice, I shall omit them, though not without causing many a woful hiatus,"

"Yes, you would be better advised to do so, even at the risk of creating many a - what did you call it? - that beautiful-ah-hiatus!" rejoined Meitei, clapping his hands quite out of season.

"I now come to England. In Beowulf is found a word 'galga' which signifies the gallows. In all probability, hanging was adopted in those very remote ages. Sir William Blackstone says that in case a criminal who was to be hanged, should not die on account of the rope giving way, the execution should be repeated. Strange to say, a contradictory statement is contained in Piers 
Plowman's Crede to the effect that however villainous a man might be, he should not be twice hanged. I am not in a position to prove which is authentic. But at least the failure of execution seems to have occurred more than once. To give an example, in 1786 that notorious knave, Fitzgerald, was put to death by capital punishment, but not until after two unsuccessful attempts. For, in the first attempt, the rope gave way under his weight for some unknown cause, just as the footstool was removed. In the second, the rope proved to be too long, so that his feet touched the ground, leaving him still breathing. In the third, however, some of the spectators rendering assistance succeeded at last in taking his life."

"Dear! dear!" put in Meitei, whose spirits were sure to rise at such a dismal tale.

"He died hard!" said my master, who, too, was brightening up.

I have a still more amusing bit or information. When hanged, they say one's statute is increased by an inch. This admits of no doubt, as it has been proved by doctors' experiments."

"That's a new device. What do you say, Kushami, to being hanged for a spell? An increase of one inch would bring you up to the 
ordinary height," remarked Meitei, turning towards my master.

"Kangetsu-kun," said my master, very seriously; "is it possible that one gets lengthened an inch, and still comes to life again?"

"Why," returned the speaker, "that's a thing beyond hope. You know, the spine is elongated by hanging; in short, it is more proper to say it is broken rather than stretched."

"Then I had better give up a trial," said my master resignedly.

It was Mr. Kangetsu's intention to deal at greater length with the physiological conditions caused by hanging. But what with Meitei's endless buffoonish jokes and my master's occasional visible yawning, the discouraged speaker stopped short and took his leave. What was his bearing and eloquence on the platform that evening, you will have to imagine; for I was not there to see.

Two or three days had passed peacefully, when suddenly about two in the afternoon, Meitei dropped in in his usual manner.

"Have you heard of Tôfū's Takanawa affair?" cried he as soon as he was seated. His tone was that of a news-boy crying an extra announcing the fall of Port Arthur.

"No, I haven't; I have not seen him of late," snapped my master as dumpish as ever. 
"I've come to give you the rare news of his stumble, and that by stealing my precious time."

"You will doubtless spin as long a yarn as usual. I declare you are a big hocus!"

"Ha! ha! ha! Pocus rather than hocus. Make a proper distinction between the two, as it is a question which concerns my reputation."

"If there be a distinction, then it is 'a distinction without a difference," " returned my master as cool as a cucumber.

"Last Sunday Tofu went, so I hear, to Sengakuji* at Takanawa, and in this cold season of all seasons, too. To begin with, to visit such a place now is just what a country bumpkin, who is a stranger to the capital, would do, isn't it?"

"Why, he did it of his own free will, and you have no right to interfere with other people's business."

"Indeed I have not. But putting that aside, you know there is in the grounds of the temple an exhibition of the relics of the Fortyseven Ronin's don't you?"

"No."

* The Buddhist temple situated in the south-eastern suburb of Tokyo, renowned for the graves of the Forty-seven Ronin in its grounds. 
"Don't know? But you have been there?" "No."

"No? Who would have thought it! No wonder you spoke in favor of Tôfü. It's a shame for a native of Tokyo not to know Sengaku-ji."

"But I can teach school all the same," retorted my master as cool as ever.

"Very well. But now let me go straight to the point. Tofu went into the exhibition hall and was inspecting the treasures, when a couple of Germans entered and inquired of him something in Japanese. As you know, he is always watching for a chance to try to air his German. He proceeded at once to avail himself of this opportunity by giving a short answer in that tongue, and he did it comparatively well. He little knew then, however, that this would get him into trouble."

"And what followed?" asked my master, carried away by the story at last.

"The Germans who seemed to take a fancy to the gold-lacquered medicine-case once owned by Otaka Gengo, * asked him if they would not sell it. And this was his interesting reply: "The Japanese are a pure high-minded

* One of the Forty-seven faithful samurai, who on the night of their assault on their lord's enemy, Kira Kōtsuke-no-suke, first broke open the gate of his mansion with a large wooden mallet. 
people; so you can hardly expect to purchase it from them.' So far so good. Subsequently he was confronted with a series of questions from the Germans, who were evidently delighted at finding a volunteer interpreter."

"About what?"

"Why, if he could have understood their questions, he would have had no trouble. They flung question after question in such quick succession that the poor linguist could make neither head nor tail of them. True, there were occasionally a few words he could make out; but even then he was not out of the wood, for they were unfortunately connected with tobi-guchi ${ }^{\ddagger}$ or kakeya, ${ }^{*}$ of which he did not know the German translation. Imagine the quandary he was in!"

"Indeed I do," sympathized my master, the situation being brought home to him as a teacher.

"By this time, their conversation attracted the attention of idle by-standers, who, one by one, flocked around them, until they found themselves the cynosure of their curious gaze. The poor interpreter blushed and became so confused that he couldn't have told whether he was standing on his feet or on

$\ddagger$ A kind of fire hook.

* A large wooden mallet. 
his head, cutting a sorry figure quite different from his first high-flown airs."

"And how did the matter end?"

"Tôfu could not long stand the trial. So he bade the Germans 'sainara'* and left the spot at a quick pace. I observed that sainara sounds a bit odd, and inquired if the common sayonara was so pronounced in his province.' No,' said he, 'it's also pronounced sayonara. But I conveniently changed it into 'sainara' for euphony's sake, as they were foreigners.' It struck me that he never forget his euphony even in trouble."

"'Sainara'aside, what did the Germans do?"

"They saw him go off in open-mouthed astonishment. Ha! ha! ha! wasn't it funny?"

"I don't see any fun in it. On the other hand, you are very funny to come on purpose to tell me such a story," retorted my master, flicking off the ashes of his cigarette into the fire-box. Just then the door bell jangled frantically, and a woman's shrill voice was heard calling out, "good afternoon." My master and Meitei involuntarily ceased talking and gazed at each other.

A lady-visitor being unusual in this house, I watched the door. Soon the owner of the

* A corruption of sayonara which means "good-bye." 
shrill voice entered rustling her double $k i$ mono of crape silk. She was a lady of middle age, say, a little over forty. Her maegami* towered like a scaffolding above her high forehead, at least half the length of her face. Her eyes which were drawn up in straight lines, making about the same slope as the Kiritōshi Slope, stood facing each other. By straight lines I mean a metaphor for narrow eyes like a whale's. But her nose alone was large, so abnormally large that it looked as if she had added the nose of another to her own. It was as though one of the massive stone lamp-posts in the grounds of Shôkonshat had been removed to a petty garden, domineering but awkward in its aspect. It was what they call a hooked nose, into the bargain. This monstrous nose seemed to have first swollen itself high in a determined manner, until, becoming conscious of its undue inflation, it stopped short and humbly drooped its head as low as the lip beneath. So that when she spoke, her voice seemed to proceed from her nose, rather than from her mouth. As a token of my respect for this wonderful

* The central part of the pompadour which in Japanese hair dressing is divided into three parts.

$\dagger$ The shrine on Kudan dedicated to the patriots who fell on the battle-field. 
nose, I will henceforth call its owner Mrs. Nose.

After the first salutation Mrs. Nose cast a sharp glance about the room and said, "What a fine house you live in!"

"Deuce take your lying compliments!" said my master to himself and carelessly puffed his cigarette.

"What's that curious mark?" incitingly remarked Meitei, looking up at the ceiling; "A rain stain or a grain of the board?"

"Of course a rain stain," replied my master.

"Very fine, indeed!" ostentatiously cried Meitei.

"Unsociable men!" thought Mrs. Nose, taking offence. For a while, the trio sat speechless.

"I've come to make an inquiry," Mrs. Nose opened her lips again.

"H'm!" said my master with the utmost iciness.

Mrs. Nose then judged it highly expedient to inform him of the importance of her family.

"The fact is," she said, "I live very near you - in the corner residence of the opposite block."

"That big European building with a storehouse? I remember, now, I did notice a doorplate with the name of Kaneda on it." My master seemed to have recollected Kaneda's 
European house and go-down, but his demeanour towards Mrs. Kaneda underwent no change for the better.

My husband should have come to have a talk with you. But he has his hands full with the business of his companies, you know." There danced in her eye a triumphant light, which indicated her belief that this shot would take effect. My master, however, was not a bit daunted. He had been feeling irritated because her manner of speaking was not at all as formal as was necessary in a lady who was paying her first call.

"Yes, he is concerned with more than one company. And what's more, he occupies an important place in all of them. - I have no doubt you know that," harangued Mrs. Nose, dealing him, in her own opinion, a decisive blow. Now, it is the way of my master to respect highly one who claims the title of "Doctor" or of "Professor" of a University; but, strange to say, his estimation of eminent business-men is remarkably low. In his eyes, a teacher of a middle school is a superior being to any one of them. And supposing he does not entertain such an idea, his slow inapt disposition naturally tells him that he is, of all men, the least qualified to get into the favor of great business-men or millionaires. However influential 
and wealthy they may be, they are the last men from whom he expects any favors. Why then should he care for their interest? He is therefore quite in the dark as to how things go outside the community of scholars. This is particularly the case with the business world, in which he has not the slightest idea of who's who and what's what. And even admitting he has some knowledge of things in that line, the names of leading business-men inspire in him little respect or awe.

Mrs. Nose, on her part, knew no more than the man in the moon that such a whimsical individual existed under the sun. She had come into contact with men of all steps of the social ladder, not one but altered his mode of reception at her proud announcement of "I am Kaneda's wife." In any meeting or in the presence of any dignitaries, "Mrs. Kaneda" was accorded due consideration. She had the more reason to toss her head before this awkward insignificant scholar. No need of giving an inkling as to what her husband was. The mere introduction "the corner residence of the opposite block" would strike him with awe, she fully expected.

"Do you know a man by the name of Kaneda?" carelessly asked my master of Meitei. 
"Oh, yes, I do," answered the other seriously. "Mr. Kaneda is an associate of my uncle's. In fact, he was a guest at his garden party the other day."

"Your uncle? And who is he?"

"Baron Makiyama," was the reply more serious than ever. My master was going to say something, but before he could. utter a word, Mrs. Nose gave a hasty turn to her position and looked at Meitei, who sat consequential in his stylish double kimono of Ôshimatsumugi and Kowatari-sarasa.

“And you are Baron Makiyama's - ? Very happy indeed to make your acquaintance. My husband often talks of the Baron, says that he is always kind and obliging to him." Her language suddenly became very polite, and she even ducked her head in a sort of bow.

"Why - er - that's nothing - Ha! ha! ha!" laughed Meitei. My master was staring at them like one dumbfounded.

"And I hear he has given the Baron a lot of trouble in connection with our daughter's marriage affairs."

"Oh — indeed!" cried Meitei, in a confused tone; he was nearly thrown off his guard by this unforeseen piece of intelligence.

"To tell the truth, she has already had a train of suitors. But considering the standing 
we enjoy in society, we cannot marry her away at a venture."

"Yes, you are quite right," joined Meitei, with a relieved look.

"With regard to this matter," she turned to my master, resuming her former disdainful tone, "I've come to ask you a few questions. You have, I hear, frequent visits from one Mizushima Kangetsu. What sort of a man is he, pray?"

"And why do you ask that?" retorted my master in any thing but an agreeable manner.

"You want to be informed," put in Meitei smartly, "of his character at large, presumably in connection with your daughter's possible marriage with him, don't you?"

"Yes, nothing is more desirable just now -."

"Then you mean you want to espouse your daughter to him?" interposed my master.

"I don't mean I want," she refuted him all of a sudden; "we would not force him by any means, having many other proposals made for her."

"If that is the case, you do not need to ask anything about Kangetsu's manner of life," repulsed my master with a show of heat.

"But at the same time you are not required to keep it a secret;" ejaculated Mrs. Nose, in a contentious mood. Meitei sat between the 
two disputants, holding his silver pipe in the way an umpire of wrestlers holds his gumbaiuchiwa, ${ }^{*}$ and saying to himself, "Hey, look sharp! Go on and do your best!"

"Then has Kangetsu pressed an offer?" questioned my master, by way of dealing a downright blow upon his antagonist.

"No, he has not pressed, but -."

"Then do you mean to say that you think he has a great mind to do so?" pursued my master, convinced that a downright blow would most tell on her.

"The matter is not yet so far advanced. But I would not deny that he is fascinated to a certain extent," replied Mrs. Nose, gaining ground in her extremity.

"Is there then any report to the effect that Kangetsu has fallen in love with your daughter?" demanded my master, in a tone as if giving her a finishing stroke.

"Yes, I should say you have about hit the mark."

My master's downright blow took little effect this time. Meitei who had all the while been gazing upon the scene with the look of

* A flat gourd-shaped fan, magnificently lacquered, used by gyôji (umpire) in deciding a wrestling match, so called from the fact that in former times a military officer used it in giving orders to his men. 
an umpire, seemed to have been excited with curiosity by this remark of Mrs. Nose's. He laid aside his pipe and pushed himself forward, and said in a highly delighted tone: "Has Kangetsu sent a love-letter to the mademoiselle? That's really amusing. Another bit of news since the new year! It will make a capital topic of conversation, I am sure."

"It's not a love-letter. He has gone a bit further. Why, are you both ignorant of it?" Mrs. Nose beat about the bush.

"Do you know?" my master put the question to Meitei, with the look of one fox-possessed.*

"No, I don't," replied the other, looking equally stupid. "You are more likely to know." He was very modest over a trifle.

"Yes, I should say you know, both of you," observed Mrs. Nose, with an exultant air.

"You don't say so!" exclaimed the puzzled pair in a breath, greatly excited.

"If you have forgotten, I will tell you," continued Mrs. Nose. "A concert was held toward the close of last year at Mr. Abe's in Mukojima. And Mr. Kangetsu attended it; you know that? On his return home that night,

* In Japan it is a common belief that foxes deceive and play all sorts of weird tricks on human beings, and in many cases "possess" them. 
something happened at Azuma Bridge, didn't it? - I refrain from going into details, for fear it might cast a slur upon his honor. Let it suffice to say that the evidence is sufficient. What do you think?" So saying she straightened up her person and placed her hands which sparkled and glittered with a profusion of diamonds, upon her knee. Her great nose looked more imposing than ever, and Meitei as well as my master seemed to have been thrown quite into the shade beside its sublime grandeur.

Even Meitei, to say nothing of my master, was apparently taken aback by this bolt from the blue. For a time, both of them sat agape, like invalids who had just recovered from a recent attack of fever. However, when their amazement had subsided, and they began gradually to regain their usual equipoise, and the humour of the thing striking them almost simultaneously, they looked at each other with twinkling eyes, and with one accord burst out laughing. This was rather more than Mrs. Nose's ponderous mind could grasp. She turned upon them a sharp reproachful glance for their unseasonable mirth, as she thought.

"And so that Miss B. proves to be your daughter? Stirring news! Yes, I see you are 
right, madam. There is now little doubt that Kangetsu has set his affections upon mademoiselle; what do you say, Kushamikun? - Now that the veil is drawn aside, let us confess all."

"Hum!" was the only reply of my master.

"Yes, this is no occasion for you to be reserved. The snake is already out of the grass, you know," gloried Mrs. Nose.

"Yes, we have no alternative, in the present circumstances, but to acquaint you with all we know of Mr. Kangetsu. How now, Kushamikun! Are you not the host? Mind your duty, man! Your smirking is to no purpose, sir. Upon my word, I see now what it is to have a secret. However studiously one may keep it to oneself, it is sure to leak out someway or other. - But it is a wonder, Mrs. Kaneda, how you came to get scent of it. Yes, it is simply astonishing." Meitei alone had his say.

"We are not wholly without wits, you know," was the sarcastic reply.

"I should rather say you have all your wits about you. From whom on earth did you hear the news?"

"From the Kurumaya's wife who lives just behind this house."

"The Kurumaya who keeps that black cat?" questioned my master, raising his eyebrows. 
"Yes, she has been an excellent instrument in carrying out the inquiry relating to $\mathrm{Mr}$. Kangetsu. Whenever he came here, the good dame, at my request, was to inform me of all that he said; I was anxious to learn how he would talk, you know."

"That's really a bit off, I must say!" growled my master.

"Why, it's of little concern to me what you do or say. What I want to know is solely about Mr. Kangetsu."

"Whomever you might want to know of At all events, a hateful thing is the Kurumaya's wife," vociferated the angry host.

"But she is at liberty to stand outside your, fence," retorted Mrs. Nose unblushingly. "If you don't like to have your conversation overheard, you had best talk in a whisper, or, better still, remove to a larger house. It's not the Kurumaya's wife alone," she continued. "I have been apprised of all sorts of things by the samisen teacher who lives in the new road."

"About Kangetsu?"

"No, it's not only about Mr. Kangetsu," she inserted a word of intimidation.

But nothing daunted, my master rapped out: "That musician is a stupid fellow who is always on stilts with a petty display of grace and elegance." 
"Fellow? Very sorry, sir; but she is a woman. Don't put the saddle on the wrong horse, please!" Her language began more and more to betray her personality. To all appearance, her business here was to pick a quarrel. On the other hand, Meitei was as usual in his element. He remained a silent listener to this controversy, with secret interest. Tekkaisennin* could not have gazed upon a cockfight with more indifference.

My master who thought he was no match for Mrs. Nose in the exchange of abuse, was obliged to shut his mouth for a while.

"You talk," he said after a few seconds, as an idea occurred to him, "as if the love were all on Kangetsu's side. But from what I have heard, the case seems to have a slightly different aspect, doesn't it, Meitei-kun?" he called for his friend's reinforcement.

"Yes," replied the other, "according to Kangetsu's statement, your daughter first fell ill and gave herself away in her delirium."

"No, nothing of the sort!" she gave a peremptory denial.

"But Kangetsu said he actually heard it from Dr. A's wife."

* An ancient hermit supposed to have lived in China. He is represented in pictures as a man of placid mien. 
"But that was a pure design on our part. I asked the lady to see how he would feel before the alarm."

"And the lady assented, knowing the real state of affairs?"

"Yes, but we could not very well make such a request, without untieing our purse strings. With this and that we have spent no small sum of money, you know."

"Then you are determined not to return until you have hunted out every particular relating to Kangetsu?" was the question put in a brusque, curt manner very unusual for Meitei, since he also felt hurt at her manner.

"Come, Kushami-kun!" he went on, "let us tell all; we lose nothing by that, you know. Now, madam, Kushami as well as I will let you know all about Kangetsu, which we deem proper to impart. You would do well to put your questions in order, and ask them one by one."

To this Mrs. Nose agreed, proceeding slowly with her inquiry. Her language, once very intimidatory, became polite again when she spoke to Meitei. "I hear," she began, "that Mr. Kangetsu has the degree of Bachelor of Science. May I ask what is his speciality?"

"He is making a study of terrestrial magnetism in the Post-Graduate Department of the Imperial University," replied my master 
seriously. Unfortunately for her, this technical expression was Greek to her. She looked rather blank as she said "Ahem!"

"Will that study make him a Doctor of Science?" she asked a moment later.

"Do you mean to say that your daughter will not give her hand to him unless he becomes one?" queried my master, with displeasure.

"Yes, the simple Bachelor degree is so very common, you know, it's almost as common here as millionaires in America!" was the cool reply. My master turned to Meitei with a look of increased displeasure.

"Whether he will become a Doctor of Science or not is more than we can warrant," inserted Meitei, who, too, was no less annoyed. "Therefore ask another question, please."

"Is he even now at terrestrial — what d'you call it?"

"Two or three days ago, he spoke on the result of his dynamical study of hanging, at a meeting of the Scientific Society," said my master, in a careless manner.

"Hanging! Ugh! I say he has a lot of whims about him. I fear he will never be made a doctor by studies of hanging and the like."

"Perhaps not, if he makes an actual experimentum on his corpus vile; but he might be 
created one so far as his elucidation of the dynamics of hanging is concerned."

Mrs. Nose only said, "Is that really so?" and studied my master's countenance. Poor woman! She hadn't the slightest conception of what corpus vile was, and as for dynamics it might be Choctaw or Christian Science for all she knew, and so she was much put out in consequence. But she apparently thought it improper to let her ignorance be seen or to venture a question on what might be a trifle or of common knowledge. So she tried to divine the meaning from the expression of my master's face, which, however, was noncommittal.

"Is he investigating any thing of a simpler nature, besides?"

"Well, some days ago, he wrote a treatise on the 'Stability of an Acorn and the Revolution of Planets."

"I wonder that such a trifling thing as an acorn should be made a subject of study at a college."

"Well, I cannot answer for that," said Meitei, with solemn mockery; "but seeing it is treated of by Mr. Kangetsu of all scientists, I should say it forms a theme worthy of research." 
Mrs. Nose, abandoning scientific research as beyond her powers, now changed the course of the conversation. "By the way," she said, "he had two of his front teeth broken on New Year's Day through eating mushrooms, didn't he?"

"Yes, and I once saw a piece of Küyamochi sticking to those very teeth," responded Meitei, with sudden gaiety, feeling more at home in this style of conversation.

"What a lack of grace, to be sure! He should have used a toothpick."

"I'll give him advice to that effect the next time he comes," said my master, chuckling.

"His teeth must be very frail to give way when eating mushrooms. What do you think?"

"I cannot very well say anything to the contrary, can you, Meitei?"

"Nor can I, either. His broken teeth give him an air of pathetic loveliness, though. $\mathrm{He}$ has not had them attended to yet, and it is amusing to see them still remain a lodgingplace for Küya-mochi."

"I wonder if he cannot afford to have them seen to, or is it his whim to leave them as they are?"

"Set your mind at ease, madam," rejoined Meitei, whose humor was recovering by 
degrees; "I assure you that he is not likely to remain 'Mr. Maeba Kakenari'* forever."

"If you have anything he has written, a letter for instance," said Mrs. Nose, proposing a new topic," I should like to have a look at it."

"If his post-cards will answer your purpose, I might show you a heap." So saying, my master brought from his study a bundle of them, numbering some forty.

"I do not want so many - two or three will do."

"Well, let me pick out some good ones," interrupted Meitei. "This is a rather suggestive one." And he handed her a picture card.

"My! does he paint? What a clever-fingered man he must be! Well, let me look at it." Staring hard at the card she suddenly cried: "Oh, dear me! This is a badger. I can't make out why he chose a badger of all animals. - But curiously enough it looks like one, anyhow." And she gave a slight nod of approval.

"Read the lines on it," suggested my master, smiling.

In a drawling sing-song not unlike that of a kitchen-maid perusing a paper, Mrs. Nose began to read thus: -

* Literally to leave one's front teeth broken; here humorously used as a name. 
'On New Year's Eve, a pack of badgers who make their home in a mountain assembled for a ball. They romped and danced to their hearts' content. This was their song: Come, comrades, come! Let's be merry this New Year's Eve, for no human climber will come to disturb us. Suppokopon no suppokopon! ‘

"Pish!" grumbled Mrs. Nose, "this is simply bosh!"

"How do you like this one?" said Meitei, giving her another card, on which was represented an angel in a feathery robe playing on a lute.

"Her nose seems to be rather too small."

"Why, madam, that's the ordinary size of nose. But the nose apart, read what is written,"

The writing ran: -

"In days of yore there lived in a certain country an astronomer. One night he was, as usual, intently observing the stars from a tower, when a beautiful angel appeared in the sky, and began to perform sweet music unknown to human ears. The astronomer stood entranced with the wonderful strains, forgetting the piercing cold to which he was exposed. The dawn of day revealed his lifeless form white with frost. This is a true story, so says an old man who cultivates his imagination for the production of his facts." 
"What a story! It signifies nothing, — regular nonsense. And still he passes as Bachelor of Science! He had better devote a little of his time to reading some popular literary magazine.” Poor Mr. Kangetsu was mercilessly attacked.

"How's this?" said Meitei now in a merry mood, taking out a third card. This one showed the picture of a sailing boat in black and white, and beneath it there was, like the rest, something in writing, which read thus:

'At the inn I lodg'd the previous night, I met a girl, a pleasing sight At the cry of sea-gulls from the coast, She woke, and ah, then, she looked like a ghost!

Her eyes were red and her face tear-stained The reason for this is soon explained Her sad mind wander'd far, far away Where her father, a shipwreck'd sailor, lay,

And while his corpse became the toy of the waves. And failed to obtain the rest that it craves."

"My! That's very expressive, - yes, it's worthy of praise. He certainly knows what's what."

"Oh, does he?"

"Yes, I dare say it could be sung to the accompaniment of the shamisen." 
"And if so, it might be called a regular song. How d'you like this?" And Meitei held out still another card.

"Quite enough, thank you. I now understand that he is not at least boorish in his way," in a very self-satisfied tone.

Mrs. Nose seemed to have ended her inquisition about Mr. Kangetsu. "You must have found me very much in your way; I hope you will kindly keep it secret from Mr. Kangetsu that I have called here," was the selfish request. Her intention was evidently to prosecute a close inquiry into Mr. Kangetsu's manners and customs, so to speak, and still to have him ignorant of things concerning herself. My master and Meitei only said "Very well, madam," drily.

"I will repay your kindness one of these days." With this assurance, she stood up. The two men saw her to the door.

"What a monster!" They exclaimed simultaneously, the moment they were seated. A titter was heard from my mistress in a back room; her pent-up mirth had long been struggling for a vent.

"Madam, madam!" called out Meitei; "A typical tsukinami has been here, and a rare one, too. Now, have a hearty laugh; there is no longer any reason why you shouldn't." 
"To begin with, I hate her face," grumbled the offended host, in a bitter tone. Meitei instantly followed with the remark: "And how the gigantic nose lords it over her face with an air of supremity! Nose, did I call it? Nay, rather nose plus nose, proboscis!"

"It's curved, into the bargain."

"Yes, slightly hump-backed. A humpbacked nose is rather out of the common run," with a merry laugh.

"A domineering, brow-beating, husbandbadgering face!" still in a vindictive tone.

"Her countenance," observed Meitei in his usual odd way, "is such as found no demand in the 19th century and will remain shopworn all through the 20th."

Just then my mistress came out, and with a sensitiveness peculiar to the weaker sex said: "If you talk so ill of her, the Kurumaya's wife will carry the tale again, I fear."

"All right, madam. That may serve to do her some good."

"But then it is mean to make such personal remarks. She was born with that nose; it can't be helped. - Besides, you are too harsh to talk so of one of the gentler sex." My mistress chose to plead in favor of Mrs. Nose's nose, and indirectly of her own looks. "No, we are not harsh at all," returned her 
husband, "she is not properly to be called a woman, but a silly goose; what's your opinion, Meitei?"

"May be. But anyhow she is a hard customer to deal with. And you had the worst of it."

"In what light does she regard a teacher, I wonder?"

"She considers him no better than the Kurumaya behind your house, I believe. The best way to secure respect from such a person is to become a Ph.D. or D.D. or S.T.D. or Litt.D. or something of that kind. And I think it was a great mistake of yours that you didn't establish yourself as such, don't you, madam?" Questioned Meitei, turning his eyes upon my mistress, laughing.

"Ah, but he has a poor chance to gain such distinction," returned the other. Poor teacher! He was given up even by his wife.

"Don't hold me so cheap, woman! I may become one by and by. You know not anything of great men. An ancient philosopher called Socrates published an undying work at the age of ninety. And it was also at the advanced years of nearly one hundred that Sophocles astonished the world with his masterpiece. Again, Simonides worked out an ingenious poem at eighty. And even I -” 
"Tush! Such a dyspeptic as you can hardly be expected to live so long," broke in his wife, estimating her husband's life.

"How dare you talk like that! Go and ask Dr. Amaki if I am destined to a short life. - I declare it is your want of care that has caused me to be lightly esteemed by that woman; you should not have had me dressed in these patched kimono and rumpled black cotton haori. I will wear such as Meitei's from tomorrow; mind you have them ready.

"Why, you have no such rich clothes. It was after she heard the name of his uncle that Mrs. Kaneda became polite towards Mr. Meitei. It's not the fault of your dress." My mistress thus slipped out of the corner into which her husband tried to force her.

The word "uncle" caught my master's ear. "I hear for the first time to-day that you have an uncle," said he, as one suddenly reminded of something; "I have never heard you talk of him. Is it really true?"

"Uncle, surely!" cried Meitei, as if the question were an expected one: "And an uncle awfully stiff-necked, too. He has lived on to 'strut and fret his hour upon the stage,' the earth, from far back in the 19th century down to this day," looking alternately at the couple. 
"Ho! ho! ho!" laughed my mistress. "How humorously you talk! And where is he living?"

"He lives at Shizuoka, and that in no ordinary way. He has still a chommagè (queue) on his head. Just think of it! If advised to wear a head-dress, he proudly says that, though stricken in years, he does not feel the cold enough to need one. When told to lie in bed late as it is cold, he insists: 'Four hours' sleep is enough for any man; it is an indulgence to take longer repose.' And he is astir while it is yet dark. 'It is by force of the assiduous practice of years,' he boasts, 'that I have accustomed myself to limited slumber. True, I found it hard to get up early while young, but now, thanks to my then efforts, I have attained the happy result of acting up to my will at pleasure.' Now, isn't it natural that one gets less sleepy at the age of sixtyseven? Out upon his practice and effort! Still the stubborn old man believes it the outcome of his self-control. And then he never goes out without an iron fan in hand."

"What for?" broke in my master.

"I can't tell. He simply carries it. Very likely he considers it a sort of cane. But a strange thing occurred the other day," addressing this to my mistress, who acquiescently replied "Indeed!" 
"This spring he suddenly wrote asking me to send him as soon as possible a frockcoat suit, and a silk hat. Surprised at this unlooked-for request, I sent him a card of inquiry. His answer came stating that he was going to wear them on the $23 \mathrm{rd}$, when a congratulatory meeting for our victory was to be held at Shizuoka, and that I should have the things procured and sent in good season. What was most amusing was his demand: 'Get a hat of moderate size; and have the suit made to order at Daimaru according to the measurements you think proper -,"'

"Has Daimaru taken to receiving orders for foreign clothes of late?"

"Why, no. He mistook it for Shirokiya."

"Wasn't it absurd of him to make you guess his size?"

"Yes, but that was his way of doing."

"And what did you do?"

"I could only do as he wished,"

"What a thing to do! And did the suit answer the purpose?"

"Yes, it did somehow or other, I fancy; for I saw by a local paper that Makiyama Senior was seen on the occasion in an unwonted frock-coat, but with his usual iron fan in hand - '"

"Seems he carries his favorite fan everywhere." 
"Yes, when he dies I mean to put it into his coffin that he may carry it to the other world."

"But it was fortunate that the dress as well as the hat chanced to fit him well."

"Far from it. I, too, had been pleased under the same impression, until, a short time after, a parcel from him reached me. Thinking it contained some acknowledgment for my little service, I made haste to open it. What was it? The very same chimney-pot! There was inclosed a note which ran: 'The hat you kindly procured me is a bit too large. You will oblige me by taking it to a hat-maker to have it remodelled. The cost will be remitted by cheque." "

"Really he lacks tact!" exclaimed my master, with a look of satisfaction; he saw there existed a less tactless fellow than himself in the world. "And what did you do?" he asked after a while.

"Why, there was nothing to do but to give myself the pleasure of keeping it for my own use."

"Ah, is that the hat in question?" my master smiled.

"Is that man a Baron?" questioned my mistress, with an expression of wonder.

"Who do you mean?" 
"That avuncular wielder of the iron fan."

"No, he is a Chinese scholar. He devoted his younger days to the study of Chinese Classics, such as Shushi-gaku $\ddagger$ at Seidô,* with the result that he is in duty bound still to wear chommagè even under electric light. A man of the old school cannot be helped." And Meitei rubbed his chin with assumed carelessness.

"But you said 'Baron Makiyama' to that woman, if I remember rightly."

"Yes, you did," rejoined my mistress, supporting her husband for once in her life. I heard you say so from the sitting room."

"Oh, did I really? Ha! ha! ha!" laughed the other in a very nonchalant manner. "That was a careless handling of the truth. If I had an uncle in the nobility I should be at least the head of a bureau by this time."

"I thought I smelt a rat," said my master, with a strange look of mingled joy and worry.

"My! How could you tell such a story in that serious matter-of-fact way! You are a

$\ddagger$ The works of Shushi, an eminent Chinese commentator of Confucian Classics.

* The great temple of Confucius at Hongô in Tokyo, where samurai used to assemble periodically for the investigation of Chinese literature. It is now utilized as an Educational Museum. 
good hand at drawing the long bow!" cried my mistress, considerably excited.

"But that woman can beat me."

"But you would not easily yield the pas to her, I am sure."

"But, madam, I am a simple 'blow hard' while she is a cunning liar who has always some detestable aim in view. The God of Comedy will be obliged to heave a sigh over the lack of human intelligence which is unable to distinguish between inspired humor and shallow underhanded designs."

"That's a question," said my master moodily.

"They are so much alike," laughed my mistress.

$$
\text { ******* }
$$

I had never adventured myself so far as the opposite block. And as a matter of course, I had not seen what Kaneda's corner residence was like. In fact, I now heard of it for the first time. Here in my master's house the topic of business men had never found its way into the conversation. Naturally I, who feed on his rice, had learned to take no interest in anything relating to business. By chance, however, I overheard what Mrs. Nose had said a little while ago. I pictured in my 
imagination the beauty of her daughter as well as the wealth and power of her family. How could I, though a cat, now indulge in an idle nap on the veranda like a little fool?

Besides, I could not but feel sorry for Mr. Kangetsu. Mrs. Nose had shrewdly secured every possible information regarding him, even to the breaking of his two front teeth, through Dr. A's wife, Mrs. Kurumaya, and Tenshoin, the musician, whose palms she tickled with gold. But how about matters on his side? In blissful ignorance, he did nothing but smirk and fumble with the strings of his haori - too utterly silly for anything, and he fresh from college! Yet no mediocrity could hope to make an easy approach to the owner of so formidable a proboscis. My master is rather indifferent to such cases, and besides too poor to attend to them. Meitei is well off; but being a happy-go-lucky sort of fellow, he could be of no real help to Kangetsu. Then who was there that would go, like a man, into the enemy's camp and spy his movements for the lecturer upon the dynamics of hanging who was left in so wanchancy a situation? None but me! And I thought it unfair to leave the matter as it was. I am a cat, it is true, but remember I am one who keeps in the house of a scholar who reads the Moral Discourses of 
Epictetus and bangs the precious tome upon the table. And I claim to be distinguished from my heavy, doltish relations at large.

As it is, I have the heroism for such an adventure at my tail's end. I owed nothing to Mr. Kangetsu. The undertaking itself sprang, not from bull-dog courage for mere individual interest, but, in a wide sense, from the noble motive to fulfil the will of Heaven, which always maintains justice and impartiality. I know how to set my feline wits to work, when anyone dares to buzz about with another man's secret, such as the incident of the Azuma Bridge, - when he insists upon triumphantly telling everybody he meets of the information acquired through eavesdroppers in his employ, - when he makes no scruples of using any Taro, Jiro or Gombei (Tom, Dick or Harry) to incommode a worthy member of the community.

Happily the day was lovely, though I thought it a bit of a nuisance to tread on the thawing frost. But I would sacrifice my own life in the sacred cause of humanity. What then if my muddy feet stamped the patterns of plum-blossoms on the verandah? Only the maid would be put to trouble and not I. "I won't wait another day; I go this very instant," said I to myself. With a determination 
to dash through fire and water if need be, I darted out to the kitchen.

"Wait a bit," I reflected. "I have, as a cat, attained the highest pitch of evolution imaginable. In point of mental development I believe I can come up to any third-year-boy of the middle school. But what cannot be helped is the organization of my throat, which is not capable of human speech. Therefore, supposing I do succeed in stealing into Kaneda's residence and detecting all that is going on there, how can I communicate it to Mr. Kangetsu who is most concerned in this case? It is beyond my power to inform even my own master or Mr. Meitei. In that case the knowledge that I expect to secure with maybe grievous pains will be of no earthly use, just as a diamond in the ground wastes its brilliance in the unseeing soil. A stupid thing to do! I may as well desist," thought I, pausing on the kitchen steps.

But you know what it is to relinquish midway a course you have once marked out. You feel then as if the long-looked-for black clouds which had promised a refreshing shower had been suddenly swept away. Of course it is a different question when you are on the wrong path. But for the sake of what they call righteousness and humanity you should pursue 
your steps in a manly way even if you die in vain; it is the part of a man who knows his duty. To labor in vain or to drabble my feet in vain, therefore, might be the part proper for a cat. Born to the lot of one, I cannot with my tongue exchange thoughts with Messrs. Kangetsu, Meitei, and Kushami. But I have one advantage over them; I can play the spy without being in the least suspected.

To accomplish what could not be done by others had in itself something delightful. It was delightful to think that even my single knowledge of the Kaneda's secret was better than nobody's knowing it at all. It was delightful, powerless as I was to impart it, to make them conscious at least that another was in possession of their secret. In face of so many delights I could not but enter upon the adventure. "Yes, I had better go, after all," I said to myself.

I made my way to the opposite block. Sure enough, there at the corner stood a big European building like a domineering monster. Thinking the master of such a house must be a man of haughty bearing, I got through the gate and surveyed the structure. Without the least suspicion of taste, or elegance about it, the two-storied building simply towered up in a threatening manner. A regular 
tsukinami, if I were to borrow Meitei's word. I turned to the right of the porch, passed through the shrubbery, and went round to the kitchen door. It was a spacious kitchen. You might take it from me that it was may-be ten times as large as that of Prof. Kushami's. It was as good, if not better than Count Okuma's kitchen, of which the recent Nippon gave a lengthy account. Everything was so brightly polished and neatly arranged. "A model kitchen," I admired it, and slipped in on to the cemented floor which covered two tsubo, when my eye caught the Kurumaya's wife standing gossiping with a kitchen-maid and a jinrikisha-man. In the presence of suspected danger I quickly hid myself behind a pail.

"I wonder if that 'ere teacher fellow don't reelly know master's nyme," said the maid.

"In coorse 'e do," was the emphatic reply of the rikisha-man employed in the house. "Everybody around 'ere knows very well everythink abart master's manshun, and don't you fergit it. If there is anyone so iggerant, then 'e must be a bloomin' owl and deafer'n an 'ammer."

"Well, I dunno," put in Mistress Kurumaya. "That silly creecher over the wye 'oo does nawthink but poke 'is nose into 'is silly books 
hain't got the gumption to unnerstan' ennythink but littrychoor as 'e calls it, 'ud shyke ter pieces in a reg'ler fright if he noo 'oo Mr. Kaneda is. But, drat it all! theer haint no chawnce o' that, cuz the chump don't heven know 'ow old 'is little childer harr!"

"D'you mean ter sye 'e don't know 'oo master is? Well, I never! Ther ber-loo-min' chump! Of all ther - let's all go, and kick up a rar in front of 'is 'ouse and jolly well shyke up 'is bloomin' narves!"

"Yes, let's. That'll be jolly fun. Besides the himperent wretch 'ad the cheek to call mistress a lot of bad nymes, myking himpident remarks abart 'er nose an' 'er looks. 'E forgits hisself, that fellow, that 'e do. Wot's 'ee but a grinnin' baboon, tho' 'e's jolly well stuck on 'imself, the silly, bloomin' champeen ijjut."

“An' don't 'ee look fine wen 'e's goin' ter 'is bawth, 'is towl hover 'is shouljers an' 'is nose up in the hair like a walkin himmij of cornseat!" Prof. Kushami was regarded with disfavour even by the homely household drudge, the red-faced, chubby kitchen-maid.

"Wot we'd best do is to crard houtside the fence of 'is house and fire off hat 'im hall the bad nymes we can think of," the rikisha-man said.

"Yes, that mye give the stuck-up ijjut a nice 
shock, and myke 'im wise to ther fac' that 'ee is honly Mr. Mud," replied Mistress Kurumaya.

"Madam Kaneda gyve hus horders a few minits hago," he continued," to 'andle the kyse in a businesslike manner, - so she says, and not allar ourselves tubby seen, but to dishturb 'im hat 'is study by kicking up a rar that'll aggeravyte 'im beyond hendurance, the pompous ass."

"Oh, yes, in course that's ther trick," replied the other, looking as though she meant to take upon herself the responsibility of onethird of the abusing. They were then to make a raid upon the worthy scholar, it appeared. Thus thinking I secretly slid past the trio, and on into a room. My paws are a mystery. They never betray me, walk where I may. As noiseless as walking in the air or treading on a cloud. If they make any sound at all, it is that of a gong struck under water, or of a harp played behind a cavern - faint, quaint and inexplicable. You might as well try to explain the exact taste of daigô. ${ }^{*}$ Thus I am at liberty to go anywhere. A tsukinami foreign building, a model kitchen, Dame Kurumaya, a rikisha-man, a kitchen maid, a dainty daughter, a chamber-maid, Mrs. Nose, her

* A kind of cream, at once delicious and wholesome eaten by the Chinese people in former days. 
husband, - these were nothing in my eyes. I could go where I would, hear what conversation I chose, stick out my tongue, shake my tail, bristle up my whiskers, and then return with the utmost composure.

In truth, no cat in Japan is better up in such a job than myself. I sometimes even wonder if in my veins runs the blood of "Nekomata" who is noted in old story-books. The toad is said to have a luminous gem on its head. On the other hand, my tail is filled with all sorts of wisdom and, above all, a secret art handed down in the cat family, which teaches how to make fools of mankind. As you see, it was as easy for me to stroll about the veranda of Kaneda's house unnoticed as for Hercules to crush grape-jelly under his foot.

It was at this supreme moment that I was deeply struck with my own ability. And this naturally awakened in me a sense of gratitude towards my tail which I always hold dear. I thought I was bound to pay homage to my "Great Tail Deity" and offer a prayer for my further good fortune. I bowed. But presently I found the direction was wrong. I must keep my tail well in sight, and then make a humble obeisance. I turned myself to do so; the object of my worship also turned. I 
twisted my head to overtake it only to find it run ahead, leaving the same space between us. Considering how this mysterious thing stores up universal wisdom, it was no wonder after all that I was quite helpless before it. I revolved round it seven times and a half, when, getting tired, I gave up the fruitless attempt.

My head swam, and I knew not where I stood. "Move on, happen what may!" said I to myself, and broke into a devil-may-care march. Mrs. Nose's voice felt upon my ear from a room close by. "That's the place," I said as I paused before the shoji with my ears pricked up and listened with bated breath.

"That fellow of a teacher is hard up, and yet an awful humbug, I can tell you!" came her grating voice.

"Yes, a humbug! He shall have a little lesson for it. You know, I have one or two fellows from my native place attending the school where he teaches."

"Who are they?"

"Pinsukè Tsugi and Kishagô Fukuchi. I'll tell them to plague him."

I wondered where his native province was, which turned out individuals with such quaint names.

"Is he a teacher of English?" continued Mr. Kaneda. 
"Yes, from what the Kurumaya's wife says, his chief work is to teach 'readers' or the like."

"He ain't a bright teacher at any rate."

"Ain't" impressed me considerably.

"When I met Pinsukè the other day, he told me that there was a ridiculous teacher in his school, who, when asked by one of his pupils what was the English for ban-cha, seriously replied 'savage tea.' 'It still remains a joke among our colleagues,' he said; 'I am sorry that such a ninny should reflect disgrace upon the other teachers.' Probably he meant that fellow."

"Undoubtedly he's the very man. His face shows the possibility of his perpetrating such an absurdity. And yet the fellow cultivates a moustache like any gentleman of leisure."

"Impudent creature!"

If a moustache gives an air of impudence, there is not a cat which looks otherwise.

"Besides, the other fellow, called Meitei, whose name stands for "Drunkard," was such a forward, would-be wit-snapper and braggart. Drat his 'Uncle, Baron Makiyama'! I thought he looked the last man to have any relative among the upper ten."

"But you are to blame for believing such an insignificant fellow, a regular Lord-Knows-Who." 
"But the rascal went too far in diddling me with his smooth-spoken ways. I'll pay him for it, the worthless buffoon! You just wait!" she cried, in a bitter virulent tone.

Strange to say, they let out not a syllable about Mr. Kangetsu. Had they talked it over before I crept there? Or did the couple blot him out of their heads as one unworthy of their daughter's hand? This I longed to ascertain, but in vain. I had not stood there long before the ringing of a bell came from a room over the corridor. "Hullo! something is going on there, too. I must hurry," I thought and moved on in that direction.

There a woman was talking alone loudly. Judging from her voice which sounded very much like Mrs. Nose's, she could he none other than the daughter of this proud family, - the identical lady on whose account Mr. Kangetsu once came very near being drowned. Unfortunately, the shoji screened her from sight; so I could not tell whether or not a big nose predominated over her face. But judging from her manner of speaking and her heavy, porcine breathing, it was presumably a pug nose which would scarce attract the public attention. Well, her flippant tongue was running very fast, but followed by no answer. She was at a telephone, 
an instrument of which I had often heard them speak.

"Are you Yamato? Mind you reserve No. 3 of the middle gallery for me; I am going to see the play to-morrow, you know. - Understand me? - 'No,' do you say? - Why, I want No. 3 of the middle gallery reserved What? - 'Can't comply'? There is no reason why you can't; you should do my bidding. 'Ha, ha! No joking, please' did you say? — I'm not joking at all, sir! - How dare you chaff me! - Who in the name of Hotei are you? 'Chôkichi'? - I can hardly expect any satisfaction from such a numskull as you; call up the mistress to the 'phone. - What? You can see to any matter? - You are insolent, fellow. Do you know to whom you are speaking? I am Miss Kaneda. 'Ha! ha! ha! I know you full well'? What an addlepated nincompoop you are! I say again I am Miss Kaneda. What? - 'Thanks for your kind patronage'? Rubbish! Bosh! I am not here now to hear your thanks. Ah, you are laughing again; you are an unutterable idiot, a prize booby. - 'I accept the title, miss,' you say? I'll ring off if you try my patience any longer. You'll be sorry, then, won't you? well! I'm waiting! Do you hear, sir? What do you mean by your silence? Speak, sir!" 
No response seemed to come; probably Chôkichi's stock of good-nature and patience had melted away under the storm of abuse and he had done the ringing-off. The angry girl whizzed the crank round with such force that the bell set up an infernal tintinnabulation and a frightened spaniel at her feet, began suddenly to bark most furiously; thus adding to the din. Taking in the situation, I jumped down in the twinkling of an eye, and crept under the veranda.

Presently I heard approaching steps on the corridor, and a second later, the sound of the shôji sliding. I listened with breathless attention.

"Miss Tomiko, your parents are calling you," said a voice, most likely a maid's.

"Away with you!" was the unfilial reply.

"They want you; and I was sent for you."

"Botheration!" was the second rebuff.

"The matter seems to be about Mr. Kangetsu Mizushima," said the maid cleverly, undertaking to smooth the ruffled temper of her young mistress.

"Kangetsu or Suigetsu, it does not concern me. - I dislike him. He looks like a bottlegourd dancing in the wind."

Poor, absent Mr. Kangetsu was made the object of her third outburst. 
"Ah, you have had your hair dressed in foreign style. When did you have it done up in that way?" The maid drew a long breath and replied simply, "To-day."

"What a style for a maid, to be sure!" The fourth volley was fired in quite a different direction. "And I see you have put on a new han-eri." *

"Yes, the one you kindly gave me the other day. I thought it too fine a thing for me to wear, and so kept it in my trunk. But now I am wearing it in place of my old han-eri which has become shabby."

"Say! when did I make you such a present?"

"One day in the New Year season you visited Shiroki-ya and bought a han-eri - the greenish-grey one with a list of wrestlers printed on it. You said it was too plain for your own use, and gave it me. This is that one."

"My word, it becomes you well. You're a nice girl!"

"Thank you, miss."

"I don't mean it as a compliment. I meant it as sarcasm. I say now 'Shame on you!'” "Oh!"

* Literally half-collar; an ornamental piece of cloth sewn over that part of a lady's under-garment (jiban) which is exposed around the neck. 
"Why did you accept it in silence - a thing which suits you so well?"

"Oh!"

"If it suits a girl like you so well, it might not look out of place on me."

"Take my word, it would suit you perfectly."

"Then why didn't you suggest that earlier? Why do you wear it now in selfish silence? You are a mean thing!" Volley after volley came in quick succession. I was all attention, wondering what would develop next. Just then Mr. Kaneda in the opposite room called out aloud, "Tomiko! Tomiko!"

"Yes, father!" reluctantly responded the young lady, and came out of the telephone room, followed by a lap-dog, a little larger than I, whose eyes and mouth appeared drawn together to the centre of his face. I got out by way of the kitchen as stealthily as I came in and hastened home. The game was up beyond all hope.

When I returned to my homely habitation from that splendid mansion, I felt as if I had been dragged from a sunlit hill-top, down into a gloomy ravine. During my adventure I was too much absorbed in my enterprise to take particular note of the magnificent rooms and their rich furniture. But now a sense of contrast grew so keenly upon me that I almost 
longed for that so-called tsukinami residence. A business man seemed to me a greater being than a teacher after all. I sought my tail for its opinion, for I was not quite sure of my own judgment. It nodded its agreement.

When I entered the drawing room, I was much surprised to find Meitei still there. He was sitting tailor-fashion instead of in the conventional way, eagerly chatting before a hibachi* in the ash of which a bunch of cigarette mouthpieces was stuck like a honeycomb. Mr. Kangetsu, whose presence I hardly expected, was also there. My master was lying down, making a pillow of his arm, his eyes fixed upon a rain stain on the ceiling. An ordinary meeting of idlers!

"You've faithfully kept secret, Mr. Kangetsu, the name of a lady who even in wild delirium made mention of you. You can tell us now, can't you?" Meitei began quizzing.

"I would if it were solely a personal matter; but you know, it is a matter touching her reputation."

"So you cannot tell even now?"

"No, and besides I promised Dr. A's wife."

"A promise not to utter her name?"

"Yes," playing, as was his wont, with his

* Native fire-box or brazier, often of great value. 
haori cords, which were of purple, - probably not an article that could be bought in market overt.

"The color of your haori strings is rather of the Tempo fashion," remarked my master, still on his back. He never troubled himself about such affairs as Kaneda's.

"Yes, they would never do for the age of the Japan-Russia War. They had their day long ago when our fathers wore jingasa* and buttsaki-haori† with family crests. Oda Nobunaga $\S$ is said to have tied his hair in a style called chasen at his wedding. The cord he used in his hair-dressing on that occasion was probably like this." Meitei's comment was as long as ever.

"And these thongs were, in fact, on my father's coat when he joined in the campaign of Choshü," said Mr. Kangetsu, in a serious tone.

"It's high time you gave them up to a curio museum. It's a shame that Mr. Kangetsu

$\$$ The name of an era which lasted 14 years; 1830-1843.

* A broad-rimmed skull-cap usually of papiermâché, finely lacquered, with a pair of thongs to be tied under the chin.

$\dagger$ A kind of haori open at the back from the waist. $\S$ A great lord and general who lived in the Genki and Tenshô eras (some 340 years ago), liege lord of the famous Taikô Hideyoshi. 
Mizushima, the illustrious lecturer on the dynamics of hanging, should look like an antiquated survivor of feudalism."

"I would follow your suggestion if it were not for one who says these thongs become me admirably."

"And who is it that so grossly lacks good taste?" ejaculated my master, tossing himself over.

"Not one of your acquaintances."

"Never mind that. Tell me who it is."

"It's a certain lady."

"Ha! ha! ha! She is a queer one," broke in Meitei. "Shall I guess? Surely the same girl that called you from the bed of the River Sumida. What do you say to running another risk with that haori on?"

"Ho! ho! She calls me no more from beneath the waters, but from a blissful world lying to the north-west of this place --"

"Blissful? That's not the right word, if you please. Diabolical, - yes, a diabolical nose, I should say."

"Beg pardon?" asked Mr. Kangetsu, apparently puzzled.

"Nose of the opposite block popped in upon us a few hours ago. By Hachiman,*

* The Japanese Mars. 
we two were taken by surprise, weren't we, Kushami-kun?"

"H'm," assented that personage, his 'piping hot' teacup demanding all his attention.

"Whom do you mean by Nose?"

"The Right Honorable Mother of your angelic dear one."

"Indeed!"

"In plain terms, a woman called 'Kaneda's Wife' came here to institute an inquiry about you," explained my master solemnly.

I watched Mr. Kangetsu to see whether he would look surprised or delighted or abashed. His countenance, however, betrayed no emotion. His tone was as calm as ever when he asked: "And she expressed a desire to have me marry her daughter, I suppose?" His fingers were again twisting themselves about the purple thongs.

"You're clean off the mark! Her Ladyship, the owner of a commanding nasal appendage, the word 'nose' seems too - " Before Meitei could finish his sentence, my master interrupted with this ludicrous remark: "How now, friends! I've been trying all the while to compose a verse about her nose."

I heard my mistress snickering in the next room.

"What a fancy, to be sure! And have you one ready?" 
"No, only a portion. The first line is: 'On this plain, Face, doth stand the great god, Nose"”

"And what follows?"

"The second is: 'A full libation to it I propose.'”

"The third?"

"That's not on hand yet."

"Very interesting!" said Mr. Kangetsu, simpering.

"How would it do to add: "Two caverns 'neath it yawn tenebricose'?" said Meitei, whose wit never failed him.

"And how do you like this: - 'Whence thunders roar 'gainst all who dare oppose'?" capped Mr. Kangetsu.

While the three were stringing together their doggerel rhymes, they heard several voices outside, near the fence, crying, "Monkey-face! Ape! Baboon! Monkey-face! Chimpanzee!"

My master and Meitei, somewhat taken aback, but wholly undisturbed in appearance, turned a steady gaze through an interstice of the fence, whereupon the mob dispersed with a loud shout of mockery.

"What do they mean by 'monkey face'?" asked Meitei of my master, with a look of wonder. 
"I have no idea," replied the other.

"Rather poetical, isn't it?" smiled Mr. Kangetsu.

I don't know what had flashed into his mind, but Meitei abruptly stood up.

"Gentlemen," he said, assuming the airs and graces of a popular orator. "For years I have made a study of the nose from an esthetical point of view. And now I have the pleasure of imparting to you the gist of the result of my labors in Nose-ology!" My master looked up at Meitei with gaping mouth; the thing came so suddenly upon him.

"It's a regular treat," said Mr. Kangetsu, in a low tone.

"The origin of the nose has not been definitely ascertained despite my painstaking research. The first point of doubt is: Supposing it an organ of practical use, a pair of nostrils is quite sufficient; no necessity of its protruding at the centre of the face, and in such an audacious fashion, too. Then why has it come to swell out gradually like this?" pinching his own nose.

"But that nose of yours is not so badly swollen," observed my master without ceremony.

"It is at least not thoroughly depressed. Do not confuse the issue, please, with a condition 
in which two cavities are simply laid side by side. I give you to understand lest you might go astray. - In my humble opinion the trivial practice of blowing the nose continually repeated has naturally wrought such a remarkable development."

"Verily a humble opinion!" my master again inserted a bit of comment.

"As you know, when we blow the nose we invariably pinch it, giving stimulus to that particular region. Now, as the great principles of evolution tell us, that region which receives constant stimulus, reacts and develops unsymmetrically in proportion to other parts. In this way the skin gets hardened; the flesh stiffens itself until at length it is transformed into bone."

"That's too - Surely flesh is not so easily. turned to bone, at a bound as it were." Mr. Kangetsu made a protest; and a reasonable one, too, for a scientist.

"Well, you may doubt all you like," continued the speaker with the utmost coolness." But proof is more forcible than argument. For, look, there actually exists a bone. Now, the bone is formed as I have just had the pleasure of informing you. Even then there is a natural demand to which you must promptly respond; I mean you are quite often 
required to blow your nose. It is through this very process that the sides of the nasal bone are worn off, leaving a slender high prominence. - Wonderful is this process: As rain drops falling from the eaves eventually wear away the pavement; as the head of the wooden image of O-binzuru shines: with the constant rubbing of worshippers; as, in the Buddhist saying, the mysterious fumes of incense imperceptibly soak into one's clothing, behold! such a stiff clean-cut bridge of the nose is made."

"But yours is as flabby as konnyaku."*

"For the present I refrain from making any reference to my own nose, for I don't like to be regarded as pleading in favor of it. But, gentlemen, I shall give myself the pleasure of introducing you to Lady Kaneda's nose as the most gloriously developed of which the world can boast."

Here Mr. Kangetsu involuntarily broke into applause.

"But any object out of the natural order, notwithstanding its grandeur, has something awful about it which debars our approach. And so is our lady's nose; decidedly stupendous in magnitude, but too stern in appearance. Socrates, Goldsmith, and Thackeray,

* A kind of edible root, Conophallus konjak." 
etc., among the literary lights of the past, possessed by no means well-set noses. It was, however, this very imperfect cast of their noses that gave a touch of charm to their features. The adage the cardinal point of the nose lies, not in its height, but in its peculiarity $\$$ has much wisdom in it. Again, a popular saying has it, 'Hana yori dangô.' *

From esthetical value, therefore, I consider such a nose as my own of a creditable type."

This excited the pair to a sort of suppressed laughter. The speaker himself laughed right merrily.

"Well, gentlemen, what I have hitherto held forth -"

"Excuse my interruption, Mr. Speaker; but the expression 'hold forth' has rather a vulgar association and is worthy only of a stumporator. Avoid it, please," broke in Mr. Kangetsu by way of paying off old scores.

"Aha, then I will start afresh with my

$\$$ The original maxim runs: The essential value of a mountain lies in its being highly wooded, and not in its height. The humor consists in the similarity of the sound which the one has to the other in Japanese. A pun.

* Dumplings rather than flowers (the material before the esthetic). The word flowers has a corresponding sound to nose. Also a pun. 
eyes open, - wide open. Let's see. - Yes, I will now briefly discuss the proportion of the nose to the face. So far as this particular organ alone is concerned, that of Madame Kaneda will pass unrivalled anywhere; it would undoubtedly carry off the prize in a Nose Show, if there ever should be any such Exhibition of Nasal protuberances! Unfortunately, however, hers is such as independently moulded itself, without holding any conference with eyes and mouth, etc. for mutual agreement, Julius Cæsar's nose was certainly a noble one. But what would it be if we were to clip it off with the shears and plant it upon this cat's face? A heroic nose rising aloft from a space 'as narrow as a cat's brow,' as we say, would be like the Colossus of Rhodes removed to a checker-board. The disproportion altogether destroys its esthetical value. You must admit that Madam's nose is undeniably of as majestic an elevation as was Cæsar's. But at the same time let me ask you what is its surrounding facial condition. Not so coarse as this cat's looks of course. Nevertheless it is a fact that she knits her brows and draws up her narrow eyes convulsively like a hysteric okame. *

* A woman with a comical fat face. 
You would do well, gentlemen, to feel sorry for this nose whose doom it is to adorn such a visage,"

The speaker came to a short pause, when a voice became audible outside the back door, crying "Drat the brutes! They seem never to leave off their gabble about the nose."

"That's Kurumaya's wife," explained my master.

"I feel myself highly honored," resumed Meitei, "to find that my audience has been increased by the unexpected addition of a member of the gentle sex at the back door. I also deem it an unlooked-for piece of good luck that her melodious tones have served as a charming interlude to relieve the monotony of this meeting. I would fain respond to the kind regard I enjoy from my fair audience, by simplifying my delivery as much as possible. But a theme of dynamics which I am to take up now, will prove, I fear, a little incomprehensible for the generality of ladies. Please be so good as to hear me with patience." At the word of "dynamics" Mr. Kangetsu smirked again.

"What I wish to demonstrate is that the nose and the face in question are entirely out of harmony; that is to say, they are quite at 
variance with Zeising's 'golden cut.'* And I mean to deduce the fact by strict dynamical formula. Let $\mathrm{H}$ be the height of the nose and A the angle the nose makes at the plane of the face. $\mathrm{W}$ indicates the weight of the nose, of course. How now, friends! You understand well enough, don't you?"

"Not a whit," cried my master.

"And how about you, Kangetsu-kun?"

"I also have failed to get next."

"How embarrassing! Kushami aside, I fully expected that you, a Bachelor of Science, could decipher my hieroglyphics. You know, this formula forms the basis of my lecture. So its omission practically means that my labor has been in vain. But it cannot be helped. I will leave it out and go on straight to my conclusion."

"You do have a conclusion, then?" said my master, in a half incredulous, half wondering tone.

"That goes without saying. A speech without a conclusion is just like a foreign meal without a dessert. - Now listen with all your ears; I am to enter upon my conclusion this very minute. - Now from the given

* It is asserted by Zeising that the most pleasing division of a line, say in a cross, is the golden section (or cut) where the smaller division is to the larger as the latter to the whole. 
formula along with the assertions of Virchow and Weismann, etc., we must take it for granted that the heredity of a-priori condition admits of no doubt. Moreover, the psychical states which attend the former condition should be acknowledged to a certain extent as a natural effect, notwithstanding the mighty doctrine which declares the impossibility of a-posteriori character being hereditary. Consequently, a child who was born of a possessor of so presumptuous a nose has in all likelihood some peculiarity about its own. The young eyes of Mr. Kangetsu might not have detected any particular singularity in Miss Kaneda's nose. But you see, such an inheritance lies often concealed, latent, for a long period. You cannot tell, therefore, when it may grow like the prophet's gourd with a sudden change of temperature, leaving as marvellous an upheaval as that of her mother's. According to my scientific demonstration, it would be far safer for Mr. Kangetsu to bid a long farewell to this marriage question ere it is too late. I have no doubt even $\mathrm{Mr}$. Nekomata who is lying here, to say nothing of the host, is at one with me on this point."

My master rose up at this juncture, and insisted earnestly: "That's a matter of course. No one would marry such a woman's 
daughter. Not for the world! Take my advice, Kangetsu-kun, and D-O-N-T don't!' I too mewed twice just to express my agreement.

"If you are both so disposed," said Mr. Kangetsu, with not a speck of agitation. "I might as well wash my hands of the affair. But if the shock prostrate her, I am guilty - "

"Ha! ha! ha! Guilty of her broken heart, eh?"

"A fig for her broken heart!" exclaimed my master, who alone was excited. "She is a mean vixen for a dead certainty, this daughter of that snobbish shrew. How caddish and graceless of a stranger to make an attempt to catch the host on the hip."

Again a chorus of uproarious hooting burst without. "Bumptious bumpkin!" cried a voice.

"How would a large roof suit you?" shouted another.

"You brag and puff; but you do it, sad to say, after the fashion of Captain Bobadil," yelled a third louder than the rest.

My master stepped out to the veranda and scolded in a voice loud enough to drown the clamor: "Shut up, you noisy beasts! What the devil d'you mean by kicking up this din?"

"Give us some 'Savage Tea! 'Savage Tea,' we say!" scoffed the mob. 
Swift as a flash the enraged teacher dashed out of the house, armed with a stick.

"Splendid! Splendid! Give it to them! give it to them!" encouraged Meitei, clapping his hands.

Mr. Kangetsu smirked as usual, fingering his haori strings.

Following my master I crept out through a gap of the fence. And there he stood in the middle of the deserted road, leaning on his weapon, looking as wild as one possessed. 


\section{CHAPTER IV.}

As usual I stole into Kaneda's residence.

As usual, superfluous as my explanation is, is a phrase signifying an indefinite power of "often," "often" to the nth, so to speak. Man has not the monopoly of the curiosity that leads to the repetition of a thing once done, and which in turn prompts a third trial. I give you to understand that even the cat is born to this psychological privilege. When the same act is repeated thrice it goes by the name of "habit," and then passes into a necessity of life, to which my race is entitled as much as mankind.

You wonder why I haunt Kaneda's house so often? Ah, but I have a question to ask of you in advance. Why do you inhale smoke through the mouth and puff it out of the nostrils? I am sure it does you little good; helpful neither as food nor medicine. So long as you do indulge in this silly practice as if you were only doing your duty, no rigorous fault-finding, if you please, with my little hobby. Kaneda's house is to me what tobacco is to you.

Again, the term "stole into" does not justify my case. It has an odious association with thief or forbidden lover. True, I do not 
by invitation visit that worthy's mansion. But my object there is not to snatch a slice of bonito, no, never. Nor is it to have a tête-à-tête with Mr. Spaniel whose eyes and nose are spasmodically shrivelled up to the centre of his face. - Me a detective? - Flagrant injustice! In my opinion no calling in the world is more base and mean than those of detective and usurer.

I confess that my sympathy with Mr. Kangetsu once inspired in me a magnificent outburst of chivalrous spirit almost unheard of in a cat, which actuated me to enter upon a secret service on his behalf. But that was a solitary instance. Ever after that I have never stooped to behave in any way I should feel ashamed of. - Then why did I make use of the suspicious wording "stole into," you ask? Well asked! That's just the point.

I am of opinion that the sky is intended for covering everything, and the earth for resting everything upon. No man, however cynical a disputant he may be, can very well refuse to admit this evidence. Now, how much has man contributed to the creation of the sky and the earth? Not a hand's turn! Yet he remains the possessor of all to which he has little right. And even admitting his possession, there is no reason why he should exclude others. 
The idea of presumptuously limiting the vast expanse of land by petty fences and pales to mark individual ownership is in itself ludicrous. You might as well confine the boundless sky with ropes and report that this part of the heavens is yours and that another's. If you mark divisions on land and drive a bargain per tsubo, there is no reason why you should not deal out the air you breathe by splitting it into cubic feet. But you cannot effect a sale of the air nor mark boundaries in the sky. And if so, private occupation of land is anything but rational. I always hold this view as my creed, and therefore give myself free entrance anywhere.

Of course I do not go where I do not care to go. But when once a resolution is formed to go, I proceed to my destination free and easy, no matter to what point of the compass. Why then should I stand on special ceremony towards the man Kaneda alone? - But, alas! in brute force man is more than my match. "Might is right," says a proverb. As long as I live in this world of errors, I can hardly expect my just cat's claim to be accepted. If I seek to force its acceptance, there is danger of receiving a sudden blow from a fish-monger's tembin-bô, as Kurumaya's Black once did. I have reason on my side and man power on 
his. In this case I shall have to choose either to surrender my cause to slavish submission or to carry it into execution by finesse. And my choice is of course the latter. I must avoid the dreadful tembin-bô, and therefore move invisibly. I may justly enter into any human habitation, and therefore when I wish I go. Hence I steal into Kaneda's mansion.

Though not acting the part of detective, yet as I frequent this household, all sorts of goings-on naturally meet my eyes which they do not care to observe, and leave impressions on my brain which it does not wish to remember. Mrs. Nose wipes her nose with exceptional care every time she washes her face. - Mademoiselle Tomi-kô devours abekawamoch $i$ ravenously. - Mr. Kaneda eats sashimi* of tunny with a relish, and slaps his own bald pate. His humble crouched nose contrasts strangely with the pretentious one of his better half. Nor is this feature the only exception, the whole cast of his countenance being stunted. I wonder if this were not the effect of one of his boyish fights, some forty years ago, with the King o' the Kids of his

$\$$ Mochi baked and moistened and then coated with a mixture of bean flour and sugar.

* Raw fish cut in thin slices and eaten with soy usually made hot with grated horse-radish. 
neighborhood, who one day seized him by the nape of the neck and squashed his face with main force against a wall; so flat and depressed is the organ. I admit it is a calm countenance, with not a suspicion of harm about it; but at the same time somehow devoid of expression. However much he may fly into a passion, his flat face remains unchanged, impassive as a Buddha's. He is undersized, to boot. To cover and neutralize this defect, he resorts to headgear and footgear of considerable elevation. The hired rikishaman gives the shosei* his jocular criticism of this fact. The latter admires his keen observation. The enumeration of all these things would fill a volume.

My present route is to turn round the kitchen entrance and cross the garden to a rockery. Here on the safe side I cast one surveying glance at the dwelling. Not until I make sure that all is still within the shut shoji, do I venture in. In case the inmates' lively chat is audible or there is a suspicion of my being detected from the rooms, I wend my steps round the east bank of the pond, pass

* A young scholar dependent upon a well-to-do family, who helps in doing the chores for certain hours and attends to his studies for the rest of the day. 
along the storehouse, and there I am safe under the veranda before one can say "Jack Robinson.” My conscience is clear, so morally I need not hide myself nor be haunted with fear in any way. But what else can I do when I have to deal with that ugly customer called man? If the community were made up in the main of Jonathan Wilds, any virtuous man would probably acquit himself in the same way as I do.

Mr. Kaneda is a distinguished business man; so, of course, there is little fear of his brandishing a formidable weapon Jonathanwise. But I hear he is given to holding the life of his fellow-mortals very cheaply. In that case I am pretty sure he would not care a used match for that of a cat. As things go, any cat, however virtuous, is strictly required to have all his eyes about him while on this gentleman's premises. In this very vigilance: however, lies a sort of pastime for me. May be, it is solely from my love of this adventure that I betake myself there so often. As to why I like such a job, I will tell you later on when I complete a profound analysis of my brain.

Now, let me resume my intended story of which I only dropped a line at the beginning of this chapter. I pressed my chin upon the grass of the rockery, and looked out to 
see if the coast was clear that day. The spacious drawing-room was open to the balmy spring air, exposing the figures of the couple engaged in conversation with a guest. Unluckily, Mrs. Nose's gigantic proboscis was confronting my brow right across the pond. For the first time in my life I was glared at by a nose! Her partner, however, chanced to sit facing the stranger, sidewise to where I was. Thus half of his flat nose was hid from sight, making it hard for me to discern the locality of his nose. I could only surmise from where a grizzled moustache shot out in disorder, that a pair of nostrils was posed not far above. I also gave my imagination play in thinking how easy it must be for the spring breeze always to have such a smooth face to blow upon.

The guest was the most passable looking of the three. But, mind, it was only passable; so not a feature that I can particularly introduce to you as attractive. The term "passable" sounds favorable. But in his case, I am sorry to say, it was too near an approach to "commonplace," nay, it even bordered upon "vulgar." I wondered who had the misfortune to be born in this enlightened age of Meiji, with such an insignificant visage. This I could not discover unless I got under the veranda and 
listened to his conversation. "- And my wife went to his house on purpose to make inquiry -" said Mr. Kaneda, in his usual supercilious manner. Haughty in intention as his speech was, it lacked smartness: it was flat and dull like his countenance.

"I see, and he is a man who once taught Mr. Mizushima. - Yes, I see, that was a bright idea of yours. - I see." The individual full of "I sees" was the guest.

"But she failed to get what she was after."

"Yes, you might expect that from Kushami. - He has always been a wishy-washy sort of fellow, you see. And I have good reason to say so, for I once lived under the same roof with him, you see. - I can easily see how bothered you must have been." This turning to Mrs. Nose.

"It was not at all an experience I wish to repeat, I can assure you. I have never been so slighted in all my born days," snorted the other.

"Did he give you any offence? He is very pigheaded by nature, you see. - You can guess, madam, what he is like by the way he exclusively teaches 'Readers' for ten years at a stretch," observed the visitor in an oily fashion.

"The man was altogether absurd. He had a fling at my wife, as she told me - " 
"How impudent of him! - That's the worst of shallow scholars. Their petty knowledge makes them priggish, and their empty purses, cynical. - And the world has not a few of these churlish fellows either, unfortunately, you see. It's striking how they snarl at the rich, as if the latter had absorbed all their means." And the guest laughed gleefully.

"True indeed," rejoined the host, "but his case goes beyond all bounds. His waywardness arising from ignorance of the world is likely at the bottom of his misbehavior. Thinking a lesson or two would do him some good, I had him shaken up a bit."

"I see, it has turned out a good lesson, I am sure. And he needs it for his own sake," chimed in the visitor, even previous to learning what sort of "shake" it was.

"But listen, Mr. Suzuki, he is more casehardened than I thought," said Mrs. Nose in her turn. "He is said to have spoken not a word to Fukuchi-san and Tsugi-san. I felt assured that their shot had told. But no! The other day the rascal rushed upon our innocent shosei, with stick in hand. - Think of a man in his thirties plunging into such an absurdity! The man is wholly desperate, and evidently has got a tile loose."

"Dear me! Why on earth did he act so 
violently?" asked Suzuki seemingly roused to curiosity.

"Under very slight provocation," replied Mrs. Nose. "The young man had said something in jest while passing by his house, when the lunatic came bolting out, armed with a stick. Just imagine a bearded man getting angry with a mere stripling, even if he had given offence! And he a teacher, too."

"And a teacher, too, indeed," echoed Suzuki.

"And a teacher, too," reechoed the host.

The three seemed to have come to an understanding with one accord that a teacher should be dumb as an idol in the face of any sort of derision.

"Again, there was one Meitei, - a fanciful puppy who never got tired of hatching frivolous lies. I've never seen the like of him."

"Meitei? Ah, he seems to be as boastful as ever. You saw him at Kushami's? You caught a Tartar, madam. He too used to be one of my fellow-lodgers. And I often had words with him for his quips."

"His ways are enough to provoke a saint. Of course there are certain occasions when one may rightly mince the truth. I don't mean a downright lie, you know, but just a little romancing, what we call white lies, in 
short. But his are not the thing; for he lies ramstam, at random, even when he has not the slightest shadow of a reason for so doing. - It's too bad! I can't make out why he sticks to his absurd rodomontade."

"Quite right, madam. The trouble is that he makes mendacity his hobby."

"The business I hoped to transact was practically knocked on the head since he tried to lead me by the nose. The thought of it makes my blood boil. - Still I must follow convention: for, you know, I could not very well seem ungrateful after I had seen and asked of him a favor. So I sent our rikishaman over afterwards with a dozen bottles of beer. Who would ever guess his reply? He curtly told the man to be off with the uncalled-for present, as he said. Upon the rikisha-man's urging its acceptance as an acknowledgment of his service, the crosspatch dared blurt out 'I enjoy jam everyday, but never have I drunk such bitter liquor as beer.' No sooner said than he turned on his heel. — Stark staring impudence!"

"Indeed it is!" assented the guest. This time he really meant it, I am sure.

Mr. Kaneda's voice was heard after a short interval, saying: "Now to the business for which I called you to-day. The policy 
of molesting the stupid wiseacre by a side wind works pretty well, but not without certain drawbacks - " slapping his bald pate as when tickling his palate with tunny sashimi. I was under the veranda and so of course I could not witness the actual gesture. But you know, I have become well accustomed to this particular clap of late. Yes, I could tell whence it came even from my shelter, provided it was given with a little force; and that as accurately as a nun recognizes the sound of mokugyô. ${ }^{\dagger}$

"And here I should like to have your help -

"Granted, sir, granted! Anything in my power," agreed Suzuki quite slobberingly. "I know I entirely owe to your kind influence and exertions on my behalf my present removal to the metropolitan office."

From his tone it appeared that this individual was one of those who basked in the light of the great man's favour and influence. Things were beginning to take on an interesting appearance. Little did I dream that I should come in for such good "copy" having only ventured here enticed by the charming

$\dagger$ A hollow wooden box, of the shape of a fish, which Buddhist priests strike during prayer. 
weather. It was as if one had visited one's family tomb in the higan* season, and been incidentally treated to a dish of rice dumplings in the temple. What would the host request of Suzuki? I listened with breathless attention.

"That eccentric Kushami puts silly ideas into Mizushima's head, - why I don't know. For example, he has suggested to the latter not to marry our daughter, hasn't he, Hanakô?"

"Why, he has gone farther. I can give you his very words. He declared 'no one would marry such a woman's daughter. Not for the world! Take my advice, Kangetsu-kun, and D-O-N-T don't!"

"How dared he speak like that. Was he really so outrageous?"

"Oh, yes, depend upon it! Kurumaya's wife has sent in the very same information."

"What d'you' say, Suzuki-kun?" continued the host. "Things stand as you have heard, A man hard to handle, isn't he?"

"Yes, he is a regular busybody, you see. This marriage question is a thing, apart from other matters, into which a third party should not thrust his nose rudely. Simpleton

* The spring and autumn equinox set apart for the worship of Buddha. 
as he is, Kushami ought to have sense enough to see such an obvious reason. I wonder if he hasn't 'bubbles in his think tank,' as the saying goes!"

"You used to keep in the same lodginghouse as Kushami in your student days, and were, as I hear, on a friendly footing with him, at least in those days. So I request you to see and arouse him to a sense of his own interest. There might be something which he has taken amiss, but then the fault lies on his side. If he proves himself gentle and modest, I will not only give up baiting him, but see to furthering his personal welfare as best I can. But should he not improve his attitude, I will not change mine. - In short, he will lose by his perversity."

"I see! Exactly as you say! Assuredly he will be the loser, but never the gainer, by making this foolish stand, against you. I will try to bring it home to him."

"Now in regard to the question of our daughter's marriage. We have more than one proposal made for her, so cannot yet pledge our word as to having her espoused to Mizushima. But, as I have found out by inquiry, he seems not a bad candidate after all, either in point of character or of scholarship. So you might drop a broad hint to the 
young man that in case his further diligence wins him the doctorate in the near future, he may possibly obtain our consent to his marrying her."

"All right, sir. This inkling of your favour will doubtless incite him to even greater exertions."

"There is one thing I cannot understand yes, what I deem discreditable to Mizushima. And that is that he calls Kushami by the honorable title of sensei and seems to assent to all that he says. Of course we're not obliged to choose him as our daughter's partner. Therefore I don't mind whatever obstacle Kushami may put _-"

"But I am sorry for Mr. Mizushima," interposed Mrs. Nose.

"I have no personal acquaintance with Mr. Mizushima. But I am certain that he is by no means averse from an alliance with such a family as yours, which will ensure him a brilliant future."

"You are quite right," she said. "Far from being averse, he is eager for the union. Only those perplexing busybodies Kushami and Meitei try to dissuade him with a lot of rhetorical hocus pocus."

"I see! That's too bad! An act unworthy of fairly well educated men, I should say. Very 
well, I will call on Kushami and open his eyes to what is good for him."

"Have the goodness to do so," requested Mr. Kaneda. "One thing more, if you please. You know, Kushami has the best knowledge of Mizushima's personality. My wife called at his place the other day to learn about the matter, but came back none the wiser for the reason you have heard. I hope you will kindly inquire of him about the young man's character."

"I see! With pleasure. I will go there as soon as I leave here. I expect to find him back from school by this time, as it's Saturday. Where does he live now?"

"Turn the corner to the right and take the road to the left for about one chô until you find a house with a tottering black board fence. That's his place," explained Mrs. Nose.

"I see! Then it's within easy reach. I will drop in on him on my way home. I think I can find him by his door-plate."

"You may find a door-plate or you may not," she said, "for his is but a visiting-card pasted on his gate-post. The rain washes it off, you know. But when the weather clears up he puts another in its place. So you cannot rely upon the door-plate in question. I think he would save himself much trouble 
if he would affix a more durable label, say a wooden one. Indeed his peculiarity knows no bounds."

"I see! I see! But I am sure an enquiry after a house with a slanting black board fence will turn out a pretty good guide."

"Yes, undoubtedly. Besides, you can easily get to your destination by hitting upon the dirtiest house in the whole street. Ah, I have it! I can tell you a still better guide. Look for a house with a grass-grown roof!"

"I see! His house too is not without its peculiarity! Ha! ha! ha!"

I had heard enough of their conversation. Thinking I must precede Mr. Suzuki's call, or else be at a disadvantage, I retraced my steps under the veranda, turned round the storehouse to the left, crept to the other side of the rockery, got out to the street and trotted back to my old nest "with the grass-grown roof." I went round to the veranda of the sitting room with a look that would not in the least betray where I had been.

My master was lying flat on a white blanket spread on the veranda, turning his back to the bright light of the spring sun, as the tortoise does its shell. The impartial sunbeams favored with their warmth and comfort the miserable hut marked with the 
growth of shepherd's purse, as well as Mr. Kaneda's splendid drawing- room.

Only the blanket, I regret to say, was very unspring-like. The manufacturer intended it for white, the tradesman put it up for sale as such, and my master in turn invested in it as such. But then that occurred a dozen years ago. As is imaginable, its days of whiteness had long gone by and it had now passed into a time of deep-grey. Whether or not it would successfully survive this time and then be converted into an age of darker hue, was a question still on the knees of the gods. The fluff was so completely worn off all over that its warp and woof were markedly visible. It would, therefore, be too complimentary to dignify it with the full name "blanket." Better drop the last syllable and simply call it "blank", (altho' it had lost the pristine meaning of blank). But it was apparently the idea of my master to use it all through his life as he had used it one year, five years, ten years. A thrifty idea!

Well, he was, sprawling, as I said before, on that old rug. What was he doing? He was supporting his angular chin with both hands, a lighted cigarette thrust between the fingers of his right. Nothing more. May-be in his scurfy head the profound philosophy of 
the universe was fast whirling like a top. But at least his appearance gave not the shadow of an indication of such thoughts.

The cigarette was gradually consuming itself to the mouth-piece, leaving a column of ashes an inch long, which eventually dropped down on the blanket. But my master paid no attention to it, his eager eye pursuing the direction of the smoke curling up from the cigarette. Wafted by a gentle breath of air, that particular wreath was progressing in an undulating stream of rings, towards the roots of the newly washed jet black hair of my mistress. - There! I should have spoken of her earlier.

She sat with her back turned to her husband. - Ah, you call her an unmannerly wife? What odds? Mannerly or unmannerly, it differs according to how one looks upon it. My master was resting his face on his hands with a placid look of indifference, close by her back. My mistress sat thus in a happy careless mood, near his face. That was all. Decorum was an idle word in this case. They are an unconventional couple who ere their nuptial knot had been tied a single year, shook themselves free from the cumbersome chain of all ceremony and manners.

Now, my mistress, who was posing in the 
way just mentioned, had evidently taken advantage of the glorious weather to wash her long ebon-black hair vigorously with funori* and eggs. And as if making a show of her smooth hair rippling over her shoulders down below her waist, she sat sewing a child's sleeveless coat with silent assiduity. To tell the truth, it was for the purpose of drying her wet tresses that she had brought her cushion and work-box out upon the sunny verandah and seated herself solemnly with her back toward her consort. It is possible the latter of his own option had drawn himself near to her.

To take up my original story, my master was intent upon watching the smoke of his cigarette, which straggling round the gently waving hair, sent forth quivering streaks of strange sheen. But smoke does not remain in one place, because it naturally rises higher and higher. So that in order to scan the phenomenal way in which that smoke wreath twisted and twined around the hair, my master had necessarily to move his eyes.

He commenced his observation from about her waist, then gradually up her back,

* A kind or sea-weed chiefly used for washing purposes. 
shoulders, neck, and so on. When at last his eye reached to the top of her head, he saw something which fairly took away his breath. The woman he held dear as flesh of his flesh and bone of his bone, had a big round bald spot on her very crown! What was more, that part was now glittering at its best in the warm sunlight. I could easily read an amazed expression in his dazzled eyes when they made this strange discovery in an undreamed-of region. He went on staring strenuously, though his pupils contracted before the flashing object.

The first thing it brought to his mind was the brass lamp which had adorned his family altar for many generations. His ancestors believed in the Shin-shü, a Buddhist sect, the devotees of which have an old custom of allotting extravagant sums of money to their altars. He recollected that he had been used to seeing, in his younger days, a thickly gilded shrine installed in a dark recess of the storehouse of his house; - a brass lamp always hanging in that shrine; - a pith wick dimly burning in that lamp even in the daytime. His old impression that the metal utensil shone comparatively bright amidst the obscure surroundings, was recalled like a flash by his wife's bald spot. 
The lamp disappeared in the fraction of a minute, and in its stead arose the picture of the doves of the Kwannon Temple before his vision. You may think the birds have little connection with his wife's baldness. In his brain, however, there existed a close association between the two. While a child, he had made it a rule to feed the doves with peas, whenever he visited the temple. They sold peas in small reddish earthenware dishes at a farthing a dish. Now, her bald patch looked exactly like those dishes both in size and color.

"Ridiculously alike!" exclaimed my master, as if considerably moved.

"What's alike?" asked his wife, without so much as turning.

“'What's alike?' Why, you have a big bald spot on your head. Are you aware of it?"

"Yes," her hand still at work. To all appearance, the exposure raised little alarm in her mind. A model wife whose mind rose high above such trivial concerns.

"Did you get it before our marriage or after it?" he demanded. "If 'before' is the answer, I was taken in." So thought my master, though he dared not let it fall from his lips.

"I don't remember when I got it. Such a thing matters little or nothing anyway," with a philosophical look. 
“'Matters little or nothing,' you say? But it concerns your own head," a little flushed.

"Yes, I say so, because nothing but my own head is concerned." Nevertheless, she was not quite free from uneasiness; for she applied her right hand to that spot and made repeated circular strokes: "My! it has grown ever so much. Never thought it was like this." This confession no doubt meant that she was at last made conscious of the hairless space being too large for her age.

"You know, our way of doing up the hair strains this part of the head and as a result it becomes bald. - This is the case with all women, she began pleading.

"If all of your sex get bald with that speed, goodness only knows what a legion of glaring bald-pates will be made by the time they are forty. No, yours is surely the outcome of some disease; may-be, an infectious one, too. Have it attended to at once by Dr. Amaki," said my master, rubbing his head again and again.

"You interfere with another's affairs. But what about the tendrils on your chin? They have white ones among them. Now, if baldness is catching, I fear the possibility of white hair's having the same quality," she returned, a little piqued.

"But it is one thing to get one's crown as 
slippery as a kettle, and quite another thing to have two or three white hairs in one's beard. Worse still in a young woman. It's an eye-sore, - even deformity!"

"Deformity? Why then did you marry me? You wished to have me as wife, and now you call me names -."

"Married you simply because I was kept in ignorance of your incipient baldness, the fact being that I did not discover it until this very day. If you insist on justifying your cause so haughtily, why didn't you show me your head during our engagement?"

"Pshaw! Where in the world is the girl who would consent to having her head examined before she becomes a wife?"

"I might as well bear with the defect in question. But you are far below the average stature, which makes you very unpresentable.

So far as my height is concerned, you could see it at a glance, couldn't you? You evidently knew that the woman to whom you had plighted your troth was not a giantess."

"Yes, I did certainly. I never undertake to deny that. But let me confess that when we married, I fully believed you would grow taller."

"As if a woman of twenty would keep on growing! You are trying to make game of me, 
sir!" casting aside her work and twisting herself around to her husband, with an attitude ready to make it warm for him if his next word warranted it.

"But there is no reason why a woman of twenty should not grow. In fact, I promised myself your physical improvement with the nutritious fare given you after our marriage."

While my master was continuing his strange argument, with a look of a serious debater, the door-bell rang with a vigorous peal, followed by the loud call of a visitor. And so Mr. Suzuki seemed to have found Prof. Kushami's den by the growth of shepherd's purse on the roof.

Postponing the dispute to some other day, my mistress beat a retreat in hot haste into her work-room with her work-box and the sleeveless coat under her arm, while her husband rolled up the dingy blanket and flung it into his study. Just then the maid came in and handed him a card. He glanced at it with a surprised look. "Show him in," he said to the maid, as he rose and proceeded into the back-yard with card still in hand. Why he went there so abruptly is more than I can tell. And why he carried Mr. Suzuki Tôjirô's card there is harder still to explain. At any rate, I sympathized with Mr. Card who was 
obliged to go out to such an uninviting spot at the whim of that peculiar man, my master.

The maid laid a cushion in front of the alcove, and invited the guest to be seated. After she had gone, Mr. Suzuki, ran his eye round the room in a reconnoitering manner. He then examined in turn the scroll that hung in the alcove, upon which was written in imitation of the style of Beian, a noted calligrapher, these words in Chinese ideographs, "Spring visits all lands with her floral beauty;" a flowering branch of an early cherry in a cheap Céladon vase made in Kyoto, and so on. Then he chanced to look at the cushion that was left for his use. What did he see there? A cat making himself quite at home! I need scarcely say that it was none other than myself.

Then in his breast arose an agitation which hardly found expression on his countenance for a while. There was no doubt that the cushion was laid there for him. And on the cushion thus laid for him was crouching a strange animal who installed himself there with the most careless audacity. This was the first condition that disturbed his peace. If that cushion had been left unoccupied for the spring breeze to blow upon, Mr. Suzuki would have sat, out of a show of modesty, 
on the stiff uncomfortable tatami, until cordially requested by the host to be seated upon it. And who was it that made free with that which was for the ultimate possessor? If it had been a man, he might have given up the seat. But only think! It was a cat, - a fact which soured his temper more than anything else. This was the second condition that disturbed his peace. Lastly, the bearing of that cat was most annoying. Far from looking disconcerted, the impudent creature was perking himself on the seat to which he had not a color of a right, and looking Mr. Suzuki straight in the face with his round saucy eyes, as if demanding "Who are you, man?" This was the third condition that disturbed his peace.

If he felt so discontented with me, why did he not seize me by the neck and yank me off the cushion? But this he did not; he only looked on in silence. It was absurd to presume that he, a proud member of mankind, was afraid of lifting his hand against a cat. Then why did he not make short work of me by way of venting his feeling? I believe it was entirely because of his self-respect and desire to maintain his personal honor as a gentleman. As far as force is concerned, a chit of a child can handle me as it likes with 
the utmost facility. But as far as his honor was concerned, even Mr. Suzuki Tôjūrô, Mr. Kaneda's right-hand man, was quite helpless before the "Divine Cat" thus enthroned in the centre of the cushion.

However secured from public observation, he would be shorn of the dignity of a man by quarrelling with a cat over a seat. It would be too childish, even farcical, for him to make a serious case against the animal. To avoid this discredit he must put up with more or less inconvenience. The sequel was that in proportion as he tried to become master of his feelings, his inward hatred towards the cat was provoked. This accounted for the bitter glances which he cast upon me now and again. For my part, it was a treat to regard his discontented looks. So I repressed my laughter, feigning cool unconcern as best I could.

While such a pantomime was going on between Mr. Suzuki and me, my master came into the drawing room. "Why, it's a novelty to see you!" he exclaimed as he sat down.

The card was no longer to be seen in his hand. Presumably it was sentenced to an exile for life in the yard among a heap of broken crockery and other abandoned and homeless matter. I pity the guiltless thing for the 
tragic fate it met with. I had not been long meditating thus, before my master gripped me by the neck with an oath, and dashed me upon the verandah with all his might.

"Come now, be seated," he said to $\mathrm{Mr}$. Suzuki. "When did you come up to town?"

Mr. Suzuki turned the cushion upside down previous to sitting on it. "Kept so busy that I failed to drop a line. The fact is I was called back to the head office in Tokyo, you see, and - "

"Good! I haven't seen you for an age. Yes, this is the first time we have met since you went away to the country."

"Yes, and that's hard upon ten years. Truth to tell, I have often been up here since then; but every time I missed the chance of seeing you on account of being so rushed, you see. Don't take it amiss, pray. The life of a business man is, unlike yours, pretty stirring, you know."

"What a change ten summers have wrought in you!" remarked my master, observing the visitor up and down. He could hardly recognize his old chum in the stylish gentleman with neatly parted hair, dressed in a tweed of English cut, a bright neck-tie, and a gold chain glittering across his fancy waistcoat. 
"Yes, and above all I am required to have such a thing dangling," said the other, very anxious to make a display of his gold chain.

"Is that genuine?" questioned my master point blank.

"Eighteen carats," returned Mr. Suzuki, smiling; "But you have aged, too. I hear you are the father - of one child?"

\footnotetext{
"No"

"Two?"

"No."
}

"Why more? Then three?"

"H'm, total three at present. But whether it will end there or not, I cannot tell."

"Aha, I see, taking things as easy as ever. How old is the eldest - surely of school age?"

"I don't know its age exactly. Very likely six or seven."

"Ha! ha! The easy-going lot of a teacher is to be envied. I wish I had chosen to be one."

"Try the profession three days, and you will be sure to get tired of it."

"I wonder. The career seems to me to have a noble air about it, and plenty of leisure time which you can devote to your favorite studies. That of the business man is not altogether bad. No dropping into a good thing, however, so long as one remains in a position like mine. If one aspires to be a business man, one must 
climb up the ladder to the topmost rung. No good at the bottom where we are required to pay lip-homage or drink the health of those above us much against our will."

"My dislike of business men is as keen as it was in my student days. They stick at nothing in their lust for money making, - a despicable race which was known as suchônin in former days," crowing in the very presence of a business man.

"Draw it mild, my dear man. You are too much of a cynic, though I cannot deny there is something more or less sordid about them. At any rate, they can hardly succeed unless prepared to sacrifice almost everything for money's sake. - And that money has irresistible power over man. - I have just been to see a certain business man, who talked of triple blindness to attain wealth: - blindness to justice, blindness to sympathy, and blindness to shame. Fine secret, isn't it? Ho! ho!"

"And who is that fool?"

"No fool, but a man of sense, fairly well known in the business circles. Don't you know him? He resides over in the opposite block."

"Do you mean Kaneda? To the deuce with the snob!"

"Ah, I see, you are very angry with him. Why, the remark was made in joke, I take it. 
He only illustrated how hard it is to amass a fortune. It should not be regarded in the serious light in which you take it."

"Well, leave the remark as a joke then. But how obnoxious is that nose of his wife's. You said you had been at his house; then you have no doubt seen it - her nose."

"Mrs. Kaneda? She is a very sociable woman.

"Her nose - I mean her big nose. I composed a haitai-shi on that nose."

"What is a haitai-shi?"

"Don't you know? You are ignorant of the tendency of the age."

"Yes, a busy man like me, you see, has little time to spare for literature. And besides, I never had a liking for that line of culture."

"Do you know what Charlemagne's nose was like?"

"Ha! ha! I see, you are a light-hearted man. I reply in the negative."

"Lord Wellington was nicknamed 'Nose' among the rank and file. Do you know that?"

"Why so fussy about the nose? What does it signify if it be round or pointed?"

"It does signify a great deal. Do you know what Pascal said?"

"What a multitude of do-you-knows! Seems as if I came to be examined. What about Pascal?" 
"He made a remark about the nose."

"What remark?"

"He said that if Cleopatra's nose had been a little shorter, it would have effected a signal change in the world's history."

"I see!"

"Therefore I say you must not so lightly estimate the nose."

"Enough! I will pay attention to it hereafter. By the way, I have come on a little business to-day. You have an old pupil called Mizushima - er - Mizushima - what's his other name? - It's just slipped my memory. Why, yes, I mean a young man who frequents your house."

"Kangetsu?"

"Yes, yes, I see, Kangetsu. And my business is to ask of you a few questions about him."

"A marriage case, eh?"

"Yes, something savouring of that. I called at Kaneda's to-day - "

"Nose came on the same errand the other day."

"Yes, so I heard. Mrs. Kaneda told me that she looked you up with the same object, but that it was useless on account of the unlucky presence of Meitei who took the wind out of her sails."

"Served her right; for she has such a hideous nose." 
"She's a well-meaning sort, you know, and meant nothing bad, mind. She told me she was sorry she had been prevented by Meitei's presence from getting at the bottom of what she was after. That being so, she requested me to start the inquiry afresh. I've never before taken such a matter in hand. But if the parties concerned are not averse from each other, I think I might as well go between to smooth the way to their marriage. - And that's why I came here."

"You are very kind."

Though my master gave that reply coldly, he was for some reason or other inwardly moved by the words "the parties concerned." In fact, he felt as one does on a sultry summer night when a refreshing draught of air has crept into one's sleeves. Nature intended him to be a flat, obstinate man to whom refinement is an unknown quality. Yet, on the other hand, he is of a different type from the hard, unsusceptible products of so-called Civilization. The very fact that he is easily cut up over trifles goes to explain what he really is like. He had a tiff with Mrs. Nose because the latter was not to his fancy. But as to her daughter, he has no fault to find with her. $\mathrm{He}$ regards the business community with aversion, and naturally dislikes Mr. Kaneda who 
is a member of it. But why should he be prejudiced against his daughter? She has nothing to do with his interests. And Kangetsu is an old pupil whom he loves better than he does his own brother. If the two are sweet upon each other, as Mr. Suzuki says they are, it would be an act unworthy of a gentleman - Prof. Kushami is pleased to think himself such - to stand in their way even indirectly. If they are in love, - but that is the question. He must first make sure of the fact before proceeding to amend his attitude towards the case.

"Say, does that girl wish to give her hand to Kangetsu? I don't care for Kaneda and Nose; what I want to know is her own mind."

"Well — that is, I see, - er - that, you know - yes, I see, it is - er - likely she has — er - a mind to - er - marry him," was the somewhat halting reply. Truth to tell, $\mathrm{Mr}$. Suzuki had not gone to the trouble of ascertaining the bent of the young lady's mind, thinking it quite sufficient to report only the result of his enquiry about Mr. Kangetsu. Consequently, his resourceful savoir-faire seemingly failed him on the spur of the moment.

" 'Likely' is a doubtful word," observed my master, who is never satisfied until he has dealt a downright blow at any matter. 
"I see! You are quite right, for I did not express myself properly. The mademoiselle has decidedly a great mind; yes, I assure you. What? - Her mother has told me so. I hear she speaks ill of him at times."

"That girl?"

"Yes."

"That's an inexcusable thing! Why then she has not Kangetsu in her heart."

"But that's a strange tendency of the human mind, you know, to purposely depreciate those whom they love."

"No such idiot in the world!" exclaimed my master who was ill adapted to see into the many curious windings and twists and blind alleys that go to make up the secret recesses of the human heart.

"But a lot of such idiots do exist. Mrs. Kaneda, too, quite agrees with me on that point. She observed to me that her daughter must be in her inmost heart, greatly attached to Mr. Kangetsu as she had often heard her satirize him as 'a bottle gourd dancing in the wind.'"

My master was utterly bewildered before this singular explanation. All he did was to stare hard at his friend in silence, as a street fortune-teller does at his client. Mr. Suzuki, who was quick enough to take in the 
situation, judiciously adjusted his conversation to a course within the comprehension of the other.

"You can easily see how things stand," he said. "Her personal beauty, along with a tempting dowry, gives the girl every claim to choose her partner in respectable families. True, Mr. Kangetsu is a youth of great promise. But in point of social status - well, I will say 'means,' if 'social status' is not a polite term, - the match cannot be altogether considered equal. And yet her parents are so anxious about the matter as expressly to send me here. This throws a light upon the state of her heart."

Mr. Suzuki's smart explanation sounded very plausible. Seeing that my master could apparently catch his ideas this time, he breathed more freely. He knew, however, that dilly-dallying would involve him in danger of another onset. So he thought it most diplomatic to lose no time in pushing on to the fulfilment of his mission.

"Well, the circumstances are such as you have heard. They say they want no money or property on the part of Mr. Kangetsu, simply his qualification - in plain terms, his title. They do not mean to say that he can claim their daughter's hand only when he 
becomes the bearer of the degree of "doctor." No, they are not so conceited as that. - You must not misinterpret. When Mrs. Kaneda called on you the other day, Mr. Meitei interposed with a series of queer remarks no, it was no fault of yours. The lady herself commended you as an honest straightforward gentleman. - Evidently Mr. Meitei was to blame. - Well, their meaning is that they can look the world in the face if their son-in-law enjoys that honorable degree. Tell me, pray, if Mr. Kangetsu can so arrange as to present a thesis for the diploma at no distant date. - Why, if the Kanedas alone are concerned, they stand in no need of such degrees. But the trouble is with Mother Grundy, you know."

If seen in that light, their claim assumes a phase of justification. So it seemed to my master. And if so, he could not but feel inclined to have the matter arranged as $\mathrm{Mr}$. Suzuki wished. He was, as it were, entirely at the mercy of the latter. I thought my master was indeed a simple honest man.

"Then I will advise Kangetsu to prepare a thesis the next time he comes. But first of all I must make inquiry as to whether he means to marry their daughter or not."

"Make inquiry? Why, man, you will spoil the matter by appealing to such blunt means. 
The shortest cut is to sound him indirectly while you are in ordinary conversation."

"Sound him, do you say?"

"Yes, but perhaps it might not be the proper word, - well, yes, you are not necessarily required to sound him; for you are likely to get the information you need in the course of your conversation with him."

"You may. But as for me, I can't make sure unless I inquire definitely."

"Well, then, let it alone. But I think it is not fair to drive the matter into a corner by putting in one's oar unnecessarily as does Meitei. If one will not persuade the person concerned at all, one ought at least to allow him to have his own option. The case demands discretion, delicate handling, you know. Be on the alert, please, and do not put a spoke into Mr. Kangetsu's wheel when next he visits you. No, I don't refer to you; I mean Meitei. You see, there is no getting clear of his dreadful tongue."

Mr. Suzuki was censuring Meitei in place of my master, when, as the proverb goes "speak of the devil and he is sure to appear," who should walk in but Meitei by way of the customary kitchen door, as if carried there by a gust of spring wind? 
"Hullo! What a stranger! The host is apt to neglect such a frequent visitor as I am. The best way of finding a welcome here is to come once in every ten years. I see the cake is of a quality superior to the usual one." So saying, the unceremonious new-comer crammed his mouth full with a slice of Fujimura's yôkan. Mr. Suzuki was getting fidgety; my master was grinning; Meitei was munching. I observed this momentary spectacle from my seat on the veranda, which represented, as I thought, a fine "pantomimic action." If the mute discussion that is practised among the Zen priests, is called spiritual communication, the present dumb action is certainly an example, very short but very subtle.

"And so you have flown back to the capital, you old bird," Meitei was the first to break the silence. "I almost gave you up as a lifelong rover. I thank heaven for my long life to which I owe many a jolly surprise."

He made as free with Mr. Suzuki as he would with my master. As an ordinary thing old familiarity is somewhat checked when one meets one's former chum after the lapse of years. But nothing of the sort was visible in the manners of this particular worthy, the proof either of a big man or of a fool. 
"That's too harsh, man. I might lay claim to something a bit better," returned Mr. Suzuki good-humoredly. Nevertheless, he looked ill at ease, fingering his gold chain nervously.

"Had a ride in an electric-car?" my master put in a queer question abruptly.

"Seems as if I came here to-day to be chaffed. Poor old fogy as you may consider me, I am happy to remind you that I am the possessor of sixty shares of the Street Electric Car Company."

"Who would have thought it!" ejaculated Meitei. "I used to have eight hundred eightyeight and a half shares. But I regret to say that I had them all moth-eaten with the single exception of the half share. Why didn't you come to the capital a little earlier? For then I could have made you a present of some ten shares in perfect condition."

"As sarcastic as ever! But joking aside, one should never let such shares slip, the price of which is almost sure to rise year by year."

"Certainly, even a half share will bring its owner a mine of wealth after the lapse of a thousand years, I assure you. We are old hounds on this trail, both you and I. But here's poor Kushami who confounds stocks with sticks," picking up another piece of yôkan, as 
he turned to my master. The latter, following his example, also stretched out his hand to the cake-dish. It is always those positive in any matter that have claim to be imitated.

"Stocks and shares are not in my line. I only wish Sorosaki could have enjoyed a ride in an electric car, - even once," observed my master moodily, contemplating the toothmarks on the cake he had bitten.

"Sorosaki aboard an electric car?" ejaculated Meitei: "Why, he would have been carried beyond his destination to Shinagawa every time he rode. No, it's safer for him to remain as Tennen-koji, with that inscription on a takuan-ishi."

"I hear he is dead and gone," said Mr. Suzuki. "Poor soul! He was a man of good brain."

"Good brain," broke in Meitei, "but no good hand at cooking rice. When it was his turn to prepare our meal, I always preferred to eat soba otherwhere."

"In truth, I was troubled, too; for the rice he cooked was not boiled through, and yet had a scorched smell. Worse still, he served it invariably with cold uncooked $t \hat{f} f \bar{u}^{*}$ as a relish!" Mr. Suzuki, whose old discontent of a decade ago revived again, added his quota.

* A kind of food made from bean-curd. 
"Kushami was then as much attached to Sorosaki as he has been since, and they went out together almost every night to discuss shiruko. ${ }^{*}$ He now suffers the consequences in the chronic dyspepsia which makes life hideous for him. Truth to tell, however, he indulged more in a gorge of shiruko than did Sorosaki; so he ought to have departed this world earlier than the latter."

"No such logic in the world! How about your own doings? You intruded on the graveyard back of our house every night with bamboo sword in hand, and inflicted repeated blows upon guiltless grave-stones under, the pretext of physical exercise. Once you were caught by the priest in the very act, and had a good blowing-up." Meitei's past offence was exposed by the unyielding host.

"Ho! ho! Yes, I remember that the priest demanded that I stop the 'infernal noise' as it disturbed his rest. But our Right Honorable Mr. Suzuki here went further still. He actually wrestled with the tomb-stones, with the result that three or four of them were overturned."

* Food made of rice cakes boiled in and covered with a thick solution of boiled and crushed beans sweetened with sugar. 
"And how the priest foamed with rage then! How he insisted upon my restoring them to their original position. When I requested that he wait till I hired help, he urged me to do the work myself by way of penance or else the spirits of the deceased would never be conciliated."

"I never forget the sorry figure you cut then. Why, you toiled and panted in your shirt-sleeves in that place made so muddy by the last rain - "

"And you dared deliberately to stand there and sketch me! It's seldom I lose my temper, yet I confess I was stung to the quick that time. I still remember the remark you made. You do, too?"

"How can I recollect my words ten years back? But the legend upon that particular stone is still green in my memory. I wished I could carry it off when it was being replaced; it was so antique and in such perfect harmony with esthetical principles, having something of the Gothic style about it." Meitei brought in his dubious esthetics again.

"Enough! Now let's come to what you said to me then.- 'Since my intention is to make esthetics my speciality, I am obliged to make sketches of all sorts of interesting things as best I can, for future reference. Petty personal 
regard should not influence the work of so conscientious a scholar as I.' This was your cold remark. 'Unfeeling wretch.' I thought, and seizing your sketch-book with my muddy hands, I tore it to pieces."

"You clipped the wings of a promising artist, for my genius has taken no favorable turn since that misfortune. You are in my black books."

"Nonsense! I should say you are in mine."

"Meitei was as boastful then as he is now," broke in my master again, biting off the yôkan he held in his hand. "He never kept his word. And when blamed he always found some excuse or other in place of a frank apology. Once when myrtle in the yard of that temple was in bloom, he said he would publish a work called 'Essence of Esthetics' by the time the flowers withered. 'No, that's an impossibility,' I asserted. 'Judge not according to appearances' replied Meitei. 'You know not that I am a man of strong will. If you are so incredulous, let us settle the question by a wager.' I took his proposal in earnest; and a treat to a dinner at a foreign restaurant in Kanda was to be our bet, if I remember. This I accepted, feeling assured that he would never undertake the task. But I was not without some dread of the issue; I had no 
wherewithal to stand treat, you know. However, there was no indication of Meitei's acting up to his boast. A week passed, then another, and still another; yet not a page was written. In the meanwhile every flower of the myrtle faded and fell. 'Now I am in for a foreign meal,' I said to myself, and pressed the idle æsthetic to fulfil his pledge. But he cared nothing for it."

"He put it off as a joke, eh?" put in Mr. Suzuki.

"Yes, he insisted that he surpassed any of us in point of will, if not in other faculties. Who could be more brazenfaced?"

"Without writing a page?" questioned $\mathrm{Mr}$. Meitei himself this time.

"Of course! You declared proudly: I am any man's match, so far as will is concerned. At the same time my memory, I am sorry to say, is more treacherous than most people's. I had will enough to write the 'Essence of Æsthetics,' but forgot it the day following our wager. Therefore, the non-publication of the work at the appointed time is due more to the failure of my memory than to that of my will. And if it is no fault of my will, I can not see why I must treat you to a foreign repast."

"Indeed, it's very amusing. Meitei's characteristic was brought out in strong relief," 
cried Mr. Suzuki, unaccountably delighted. His manner of speaking was not what he had adopted in Meitei's absence. May be, this is the characteristic of a clever man.

"It's not amusing at all," said my master, as if still indignant.

"Sorry, very sorry for you. As compensation, you see, I am now simply instrumental in hunting for peacocks' tongues. Calm down and wait, if you please. But talking of writing, I have brought rare news to-day."

"You bring rare news every time you come. We have to be on our guard."

"But mind, to-day's is genuine rare news; yes, in the truest sense of the word, rare. Are you aware that Kangetsu has entered upon a thesis for the degree of 'doctor'? I never thought he, a scholar of singularly transcendent views, would go in for such a cheerless task. Isn't it interesting to consider that he is a man of the world after all? You must not forget to give the information to Dame Nose, who may be dreaming of Dr. Acorn now-a-days."

At the name of Kangetsu Mr. Suzuki made signs to my master with his chin and eyes. "Don't tell him" was their significance, which, however, failed to be conveyed to the host. Miss Kaneda became the object of his sympathy when he listened to Mr. Suzuki's 
lecture half an hour ago. But Meitei's mention of her mother's nick name now again made him call up the quarrel he had with her. And this recollection aroused in him a strange mixture of humor and hatred. On the other hand, the knowledge of Kangetsu's new undertaking was a source of great pleasure to him. Certainly it might be termed "rare news" as Meitei put it himself. Nay, not only rare, but at once cheerful and delightful. It did not matter whether Kangetsu would marry Kaneda's daughter or not. But it did matter that he should be made a "doctor." A poor spoiled wooden image like himself would make no great difference even if it were left incomplete, mouldering in the corner of a sculptor's studio. But a carving of admirable workmanship should be coated with gold as soon as possible. This was the thought that found its way into the teacher's mind.

"Has he really set about preparing a thesis?" he asked eagerly, shelving Mr. Suzuki's signal. "How unbelieving you are! - Whether he has chosen an acorn or the dynamics of hanging as a theme, I have yet to learn. But at any rate what he produces is calculated to be such as will astonish Nose."

At every reference to "Nose," there would float a cloud of uneasiness over Mr. Suzuki's 
features, which, however, escaped the notice of the indifferent Meitei.

"I have made further investigation of noses," he chatted on at random. "A few days ago I found in Tristram Shandy the subject of noses. If Sterne had seen Dame Nose's nose, he would most certainly have turned it to account. A thousand pities that her nose, so worthy of record, should go the way of all flesh unknown. The next time she comes here I will make a sketch of it for the benefit of æsthetics."

"But her daughter wishes to be united to him." My master made no secret of what he had heard from Mr. Suzuki. The perplexed gentleman gave wink after wink to my master, who remained a non-conductor of the electricity.

"Is the daughter of such a parent capable of love? That's a wonder. Love with no romantic flavor, but smelling of the shop, I am sure."

"Any love will do, if Kangetsu consents to marry her."

"Why, man, you were dead against that marriage question the other day. And to-day you seem in favor of it."

"I am not in favor, no I am not, but - "

"But something is the matter with you. I 
say, Suzuki, as you belong to the business world, though below par, I shall give you a piece of information. There is a certain Kaneda. And that Kaneda has a daughter. Now, what if such a man's daughter should be spliced to Mr. Mizushima Kangetsu, the world's genius? It really makes an illassorted union, - a thing which we, friends of his, can scarcely gloss over in silence. Even you agree with my opinion, don't you?"

"You talk as vigorously as ever. In fact, you have not changed a whit in ten years. And I admire your energy," dodged Mr. Suzuki, in an undemonstrative manner.

"While I accept your admiration of my energy, I shall give you another proof of greatness in my versatility. The ancient Greeks attached great importance to physical training. They sought to encourage all sorts of games by means of valuable prizes, such as oak-wreaths, and palm-branches, wreaths of parsley, and so on. But strange to say, there exists no record of their having rewarded the scholars for their attainments. And I have been wondering how it was."

"I see! That's strange indeed!" said Mr. Suzuki, humoring the other as well as he could. "Two or three days ago, however, while perusing a book on æsthetics, I happened to 
discover the reason. Many years' doubt was thus completely cleared away, and the beam of truth which shone into my mind, as liquid spouts from a tap, transported me with unalloyed rapture."

Smooth-tongued as Mr. Suzuki was, he looked flabbergasted before the extravagant language of Meitei. My master sat stooping, tapping the brim of the cake-dish with the ivory chopsticks, as much as to say, "There, the fellow has begun again!"

"And who do you think it is," continued the speaker, in a grandiloquent tone, "that has thrown light upon this contradictory phenomenon with an explicit explanation? It was no other than Aristotle, a Greek philosopher, who was called the "philosopher par excellence,' and the founder of the Peripatetic school. According to his explanation - I say, don't strike that dish! You must be all attention. According to his explanation the prizes that the Greek athletes won were of more value than the sports themselves. Therefore they served as rewards or means of encouragement. But what about knowledge? If knowledge was to be rewarded at all, something more precious must be given. And what treasure can be more precious than knowledge? Commonplace prizes would only 
tend to lower its dignity. They would fain reward it with heaps of gold piled up as high as Olympus or with all the wealth of Croesus. After trying the question in all its phases, they finally perceived that they had nothing equal to it. Since then they altogether abandoned the idea of bestowing a reward upon men of learning. You can see now that no amount of pounds, shillings and pence can come up to the value of knowledge.

"Now, friends, appreciate this fundamental truth first, and then return to the topic in hand. What is that Kaneda? Nothing but an embodiment of money. If a fresh metaphor is used, he is but a walking bank-note, and his daughter, a walking stamp, if not less. On the other hand, let us consider what sort of man our Kangetsu is. He graduated with high honors from the highest institution of learning; an energetic young scholar, who, contentedly wearing the haori-strings of the Chôshū Campaign Era, has studied the stability of the acorn day and night. As if this were not enough, he is now at a great thesis which, when once made public, will probably eclipse all Lord Kelvin's works. True, at one time he had a tragi-comic adventure while passing the Azuma Bridge. But it was in a fit of emotion common to passionate youths. 
So the event casts no discredit upon him as a wholesale trader of knowledge. If I am to express my opinion of Kangetsu with a metaphor all my own, he is a walking encyclopædia, a moving library; a gigantic cannon ball of knowledge. If a time comes when the ball bursts in the scientific world - if the ball bursts - er - it will burst, you know -"

"Here Meitei failed to command the figure which he proudly called his own. For a moment he looked anxious lest his harangue should turn out "a flash in the pan." A second after, however, he began again:

"Then any bundle of walking stamps will be blown to atoms. Therefore I declare the girl is no mate for Kangetsu. No, I do not approve of a match which might be compared to that between the most sagacious elephant and the most voracious swine. You second my opinion, Kushami-kun?" concluded Meitei. But my master was silent, tapping the dish again, while Mr. Suzuki appeared rather crest-fallen.

"There's really no such disparity, my dear fellow," he said helplessly. He had backbitten Meitei pretty severely, and so now feared the freakish professor would betray him if he ventured any imprudent remark. Better evade Meitei's pronouncement with some shift or other, and make good his escape. 
Mr. Suzuki is a clever gentleman who thinks it an up-to-date policy to avoid unnecessary resistance as much as possible. Useless argument is a relic of feudalism in his eyes. The object of life is practice and not discussion. If things run smoothly as one wishes, one's end in life is realized. And if one can walk over the course without any trouble, anxiety or dispute, one's end in life is accomplished paradise-wise. Mr. Suzuki has since graduation succeeded thru this paradise policy. Thru it he provided himself with a gold watch. Thru it he was entrusted with this confidential errand by the Kanedas. Thru it he prevailed upon my master beyond his hopes, and his business was all but over, when in came Meitei, an ugly customer out of the common run, who suspected of being capable of abnormal mental functions. As is imaginable, he got confused at the irony of circumstances. The initiators of the paradise policy were the gentlemen of the Meiji Era. The performer of this policy was Mr. Suzuki Tōjūrō. And the one who got into a mess on account of this policy was also Mr. Suzuki Tōjūrō.

"You give yourself a genteel air by being unusually sparing of your tongue, and simply say, 'There's really no such disparity,' 
because you know nothing of the affair. You should have seen how Nose talked here the other day. Stuck on business men as you are, you would have shrunk back from her. You struggled hard with her, Kushami-kun."

"She has a better opinion of me than of you, though."

"Ha! ha! ha! What self-confidence! That spirit alone makes you attend school amidst the general banter of 'Prof. Savage Tea.' In 'will' I am second to none. But I cannot be so bold. I do homage to you."

"What if the students and teachers make a noise? Sainte-Beuve was as great a critic as the world has ever produced. But when he delivered a series of lectures at the Paris University, he was very unpopular, insomuch that he was always secretly armed with a dagger, when he went out, to guard himself in the event of an onslaught from his pupils. Again, when Brunetiere attacked Zola's novels at the same college -

"But you are no professor of a university; only a teacher of 'readers.' To allude to such illustrious literati is just like a sardine placing itself side by side with a whale. You will be jeered at still more if you talk in such a fashion."

"Shut up! I am a scholar ranking with Sainte-Beuve." 
"Wonderful pride! But don't walk in the shoes of your famous friend, by going about with a dagger, as it is dangerous. If a dagger protected a Varsity professor, a pen-knife will be a fit weapon for a teacher of 'readers.' No, any piece of steel is dangerous. I'll tell you what. Go to the Nakamisè, ${ }^{*}$ get a toy gun, and walk about shouldering it. You will look picturesque then, I am sure. Don't you think so, Suzuki-kun?"

Now that a new subject of conversation was introduced, Mr. Suzuki drew a long breath.

"How delightful to hear you speak singleheartedly as usual!" he replied." I've met you both after years of absence, and now I feel as if I had passed through a narrow wynd into a wide plain. In our class of society we have to be on the qui vive as to our way of speaking. In any conversation we must verily pick our words. So there is a lot of care and constraint, you know. Free honest talking is always welcome. And nothing can better afford us this treat than the company of the old friends of our school days. Thanks to the good fortune of having fallen in with Meitei-kun, I've spent a glorious afternoon. Well, I must be saying

* The two rows of shops, mostly dealing in knickknacks and fancy goods, leading to the great temple of Kwannon at Asakusa. 
good-bye now, as I have an engagement." And Mr. Suzuki was on his feet.

"I'll be off, too," said Meitei. "I shall have to put in an appearance at the meeting of the Stage Reform Society. Let me accompany you."

"With pleasure! It is long since we have taken a walk together!"

And the two took their departure.

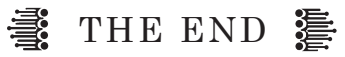




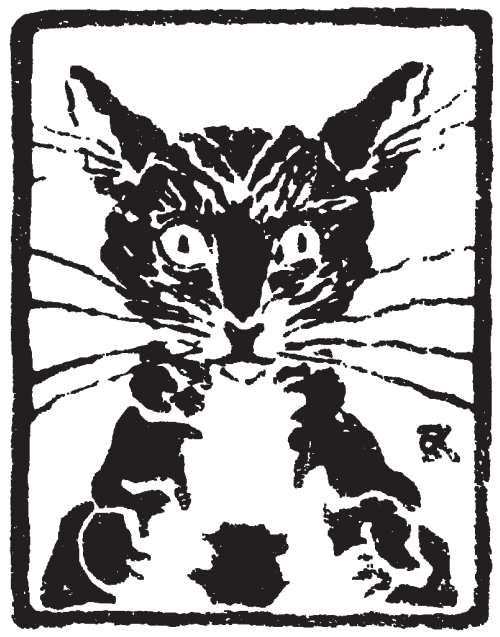




\section{NOTES}

24.16-17 Major Pendennis ... Bakin ] Major Pendennis is the social climbing title character of The History of Pendennis, 1848-50 novel by William Makepeace Thackery. Bakin may refer to Takizawa Bakin 曲亭 馬琴 (1767-1848), Japanese novelist of the Edo period.

95.1-2 Virchow and Weismann, etc. ] Rudolph Virchow (18211902) was a German physician and public health reformer; among other discoveries, he is known for naming the Virchow angle between the nasofrontal suture and the base of the anterior nasal spine. August Weismann (1834-1914) was a German biologist, author of germ plasm theory implying that acquired traits are not inheritable.

96.21 Captain Bobadil ] Character in Every Man in his Humour (1598), comedy by Ben Jonson.

103.8 Jonathan Wilds ] Jonathan Wild (1682-1725) managed a criminal empire in London while posing as a "thieftaker" or crime fighter. His life became the basis for works by Daniel Defoe, John Gay, and Henry Fielding.

108.2 ramstam ] Impetuous, precipitate; reckless; headstrong 135.15 Mother Grundy ] "Mrs. Grundy" was an unseen character in Thomas Morton's 1798 play Speed the Plough; her name became a figure for social opinion or more specifically disapproval.

149.22 Chôshū Campaign ] In 1863-64, the Chôshū clan undertook the Emperor's orders to "expel the barbarians" and attacked Western ships. They were defeated by British, French, and U.S. naval forces. 
152.15 Sainte-Beuve ] When French poet and critic Charles Augustin Sainte-Beuve (1804-1869) was appointed to the Collège de France by Louis Napoleon, his public lectures were disrupted by anti-imperialist students.

152.21 Brunetiere ] Ferdinand Brunetière (1849-1906), French writer and critic; editor of Revue des Deux Mondes, a leading member of the anti-Dreyfusards. 
